Review

\title{
Structure Refinement and Fragmentation of Precipitates under Severe Plastic Deformation: A Review
}

\author{
Boris B. Straumal ${ }^{1,2, *}$, Roman Kulagin ${ }^{1}$, Leonid Klinger ${ }^{3}$, Eugen Rabkin ${ }^{3}$, Petr B. Straumal ${ }^{4}{ }^{(}$, \\ Olga A. Kogtenkova ${ }^{2}$ and Brigitte Baretzky ${ }^{1}$
}

check for updates

Citation: Straumal, B.B.; Kulagin, R.; Klinger, L.; Rabkin, E.; Straumal, P.B.; Kogtenkova, O.A.; Baretzky, B. Structure Refinement and Fragmentation of Precipitates under Severe Plastic Deformation: A Review. Materials 2022, 15, 601. https://doi.org/10.3390/ma15020601 Academic Editor: Pavel Lukáč

Received: 3 December 2021 Accepted: 10 January 2022 Published: 14 January 2022

Publisher's Note: MDPI stays neutral with regard to jurisdictional claims in published maps and institutional affiliations.

Copyright: (C) 2022 by the authors. Licensee MDPI, Basel, Switzerland. This article is an open access article distributed under the terms and conditions of the Creative Commons Attribution (CC BY) license (https:// creativecommons.org/licenses/by/ $4.0 /)$.
1 Karlsruhe Institute of Technology (KIT), Institute of Nanotechnology, Hermann-von-Helmholtz-Platz 1, 76344 Eggenstein-Leopoldshafen, Germany; roman.kulagin@kit.edu (R.K.); brigitte.baretzky@kit.edu (B.B.)

2 Chernogolovka Scientific Center of the Russian Academy of Sciences, Lesnaja Str. 9, 142432 Chernogolovka, Russia; kogtenkova@issp.ac.ru

3 Department of Materials Science and Engineering, Technion-Israel Institute of Technology, Haifa 3200003, Israel; klinger@technion.ac.il (L.K.); erabkin@technion.ac.il (E.R.)

4 Baikov Institute of Metallurgy and Materials Science, Russian Academy of Sciences, Leninsky Prosp. 49, 119334 Moscow, Russia; straumal.peter@yandex.ru

* Correspondence: boris.straumal@kit.edu

\begin{abstract}
During severe plastic deformation (SPD), the processes of lattice defect formation as well as their relaxation (annihilation) compete with each other. As a result, a dynamic equilibrium is established, and a steady state is reached after a certain strain value. Simultaneously, other kinetic processes act in opposite directions and also compete with each other during SPD, such as grain refinement/growth, mechanical strengthening/softening, formation/decomposition of solid solution, etc. These competing processes also lead to dynamic equilibrium and result in a steady state (saturation), albeit after different strains. Among these steady-state phenomena, particle fragmentation during the second phase of SPD has received little attention. Available data indicate that precipitate fragmentation slows down with increasing strain, though saturation is achieved at higher strains than in the case of hardness or grain size. Moreover, one can consider the SPD-driven nanocrystallization in the amorphous phase as a process that is opposite to the fragmentation of precipitates. The size of these crystalline nanoprecipitates also saturates after a certain strain. The fragmentation of precipitates during SPD is the topic of this review.
\end{abstract}

Keywords: severe plastic deformation; dynamic equilibrium; steady-state; fragmentation nanocrystallization

\section{Introduction}

All methods of severe plastic deformation (SPD), including ball milling (BM) [1], high pressure torsion (HPT) [2-7], planar twist channel angular extrusion (PTCAE) [8], equal channel angular pressing (ECAP) [4,9], equal channel angular pressing with the subsequent HPT (ECAP + HPT) [4], equal channel angular pressing with following cold rolling $(\mathrm{ECAP}+\mathrm{CR})$ [10], simple shear extrusion (SSE) [11,12], or constrained groove pressing (CGP) [13], have one common feature, namely in the SPD process, the deformed sample cannot be destroyed. In other words, the deformation increases, but the shape of the sample remains almost unchanged. This applies to both continuous SPD processes, such as BM or HPT, as well as to SPD processes that consist of repeating stages, such as ECAP, SSE, or CGP. It is clear that in the case of continuous processes, it is easier to observe the evolution of the structure and the properties of the sample. Obviously, with increasing deformation, the concentration of defects in the material increases. These are vacancies, interstitial atoms, dislocations, grain boundaries (GBs), and interphase boundaries (IBs). It is also obvious that the excess of accumulated defects cannot continue infinitely, although in some materials, it leads to the destruction of the crystal lattice, resulting in amorphization. 
Simultaneously with the deformation and generation of excess defects, their relaxation processes also start, for example, the annihilation of vacancies and dislocations, the flux of interstitial atoms, or vacancies to dislocations and GBs, etc. With an increase in the number of excess defects, the rate of their relaxation and annihilation also increases until the rates of these two processes becomes equal. At this moment, a dynamic equilibrium between the formation and disappearance of defects is established, and the deformation continues in a steady state regime. In this steady state, many parameters of the material reach saturation. These include grain size [14-23], microhardness [8,15,23-37], and the lattice parameter in a solid solution [2,38-41]. A natural question arises: do all the parameters of the structure and properties of the material reach a steady state (saturation) simultaneously? This review is devoted to this issue. Here, we will pay special attention to the fragmentation of the second-phase particles as well as to the reverse process, namely the nucleation and growth of second-phase particles in the material under SPD.

\section{Grain Size, Microhardness, Lattice Period}

The simplest way to observe the dynamic equilibrium between defects production and their annihilation (relaxation) it is to measure the torsion torque during HPT. The torsion torque quickly increases after the beginning of HPT and then saturates after 1-1.5 anvil revolutions in Al-, Cu-, $\mathrm{Mg}-$, Fe-, or Ti-based alloys as well as in high-entropy alloys [7,14,42-56]. For hard samples such as those of Nd-Fe-B alloys, the torsion torques saturates later, after 2-2.5 anvil rotations [42]. Other properties or structural parameters also saturate in the steady state. The most well-known example is the grain size decrease after SPD [14,17-19]. The grain size quickly decreases from several millimetres to a few hundreds of nanometers. Afterwards, the grain size reaches the steady-state and does not decrease anymore [15,20-23].

If we compare the steady-state grain size $d$ for the same material (such as copper and copper-based alloys), we can see that it depends on the SPD mode. Thus, the minimum grain size $d=\sim 15 \mathrm{~nm}$ can be achieved after ball milling (Figure 1) [1]. This is followed by HPT with $d=80-120 \mathrm{~nm}$ [2-7]. The $d$ values for PTCAE [8], ECAP [4,9], ECAP + HPT [4,29], ECAP + CR [10], SSE [11,12], and CGP [13] are higher. The same tendency is also observed for aluminium and Al-based alloys [57].

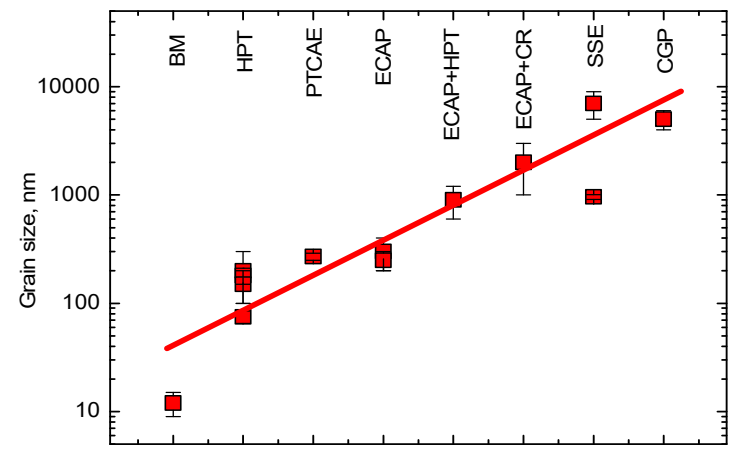

Figure 1. Steady-state grain size in copper subjected to the different SPD modes: 1 -Ball milling (BM) [1], 2-HPT [2-7], 3-PTCAE [8], 4-ECAP [4,9], 5-ECAP + HPT [4], 6-ECAP + CR [10], 7-SSE [11,12], 8-CGP [13].

The HPT temperature, pressure, and strain rate also influence the steady-state grain size $d[42,43]$. Thus, $d$ decreases as the melting temperature increases (characterizing the strength of atomic bonds), decreasing the processing temperature and increasing the activation energy for self-diffusion and specific heat capacity $[43,58]$. The effective strain also plays an important role in reaching the dynamic equilibrium state. Thus, in case of HPT, the effective strain in the middle of the sample is always lower than it is in the sample periphery. As a result, the critical value of effective strain for the dynamic equilibrium is reached first at the periphery, where there is a lower effective strain that in the centre. 
For example, at a low number of anvil rotations, the grain size reaches its maximum in the middle, and the microhardness is at its minimum [15,25-37]. With increasing number of rotations, the difference between sample centre and periphery decreases. It totally disappears when the effective strain in the middle also reaches the critical value for the dynamic equilibrium.

It is important to say that the grain size is a real steady-state value in the dynamic equilibrium. This means that the steady-state $d$ can be reached both "from the top" and "from the bottom". For example, if one begins the HPT of the coarse-grained steel sample, one quickly reaches $d=15-20 \mathrm{~nm}$ [22,59-66] (Figure 2). On the other hand, if one starts the HPT of a steel sample produced by mechanical alloying with $d=10 \mathrm{~nm}$, the grains do not become smaller. To the contrary, they grow up to the same steady-state value of 15-20 nm during SPD (Figure 2) [65]. A similar phenomenon of $d$ decrease "from the top" and $d$ increase "from the bottom" to the same steady-state value was observed also in nickel $[67,68]$ and copper [69].

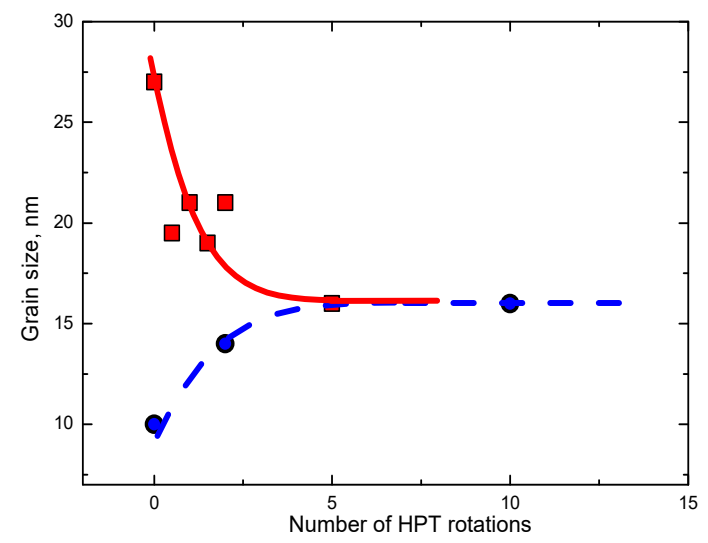

Figure 2. Grain size $d$ after HPT plotted vs. number of rotations for pure coarse-grained steel sample (solid red squares) [60] and nanocrystalline steel produced by mechanical alloying (solid blue circles) [66].

The explanation of this phenomenon is that the grain refinement processes compete with the nucleation and growth of new defect-free grains. If the grains are large in the initial state, then the intersection of dislocations, grain boundary sliding, deformation twining, etc., prevail at the beginning, and the grain size decreases. The driving force for the nucleation and growth of new defect-free grains is the decrease in the excess energy of the dislocations and interfaces disappearing during the growth of new grains. This driving force increases as the effective strain increases, and grain refinement slows down until the dynamic equilibrium is reached "from the top". If the grains are large in the initial state, then they grow quick until the grain fragmentation mechanisms have enough space to work and to counteract the grain growth. Thus, the dynamic equilibrium is reached "from the bottom".

SPD not only leads to quick grain refinement but also to changes in mechanical properties. For example, a large amount of experimental data has been collected on the Vickers microhardness during and after the SPD of Cu-, Al-, Ti, Mg-alloys, steels, etc., [15,23,30-37]. Normally, microhardness increases during SPD [15,23,30-37] and correlates with tensile strength $[14,18,19,27,30,70-72]$. The microhardness and tensile strength increase with the increasing rotation angle for HPT as well as with the increasing number of ECAP passes [32]. The mechanism explaining this phenomenon is the Hall-Petch hardening that is driven by grain refinement [73]. A few exceptions only underline this fact. Thus, the Hall-Petch hardening in $\mathrm{Al}-\mathrm{Zn}$ alloys competes with solid solution softening due to the decomposition of the $\mathrm{Al}(\mathrm{Zn})$ solid solution. The grain size continuously decreases during HPT as usual (Figure 3a-d), but the alloy becomes softer (Figure 3e) [8,26]. 


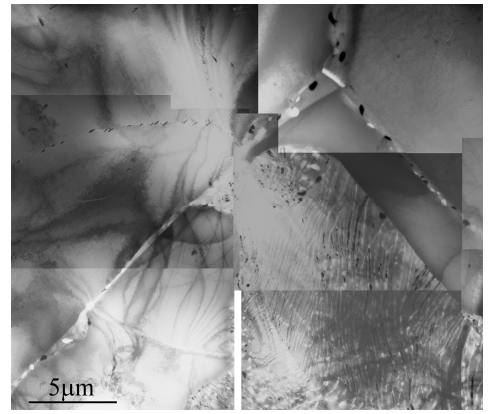

(a)

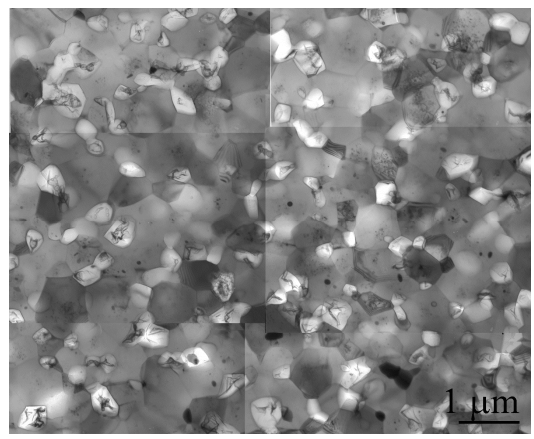

(d)

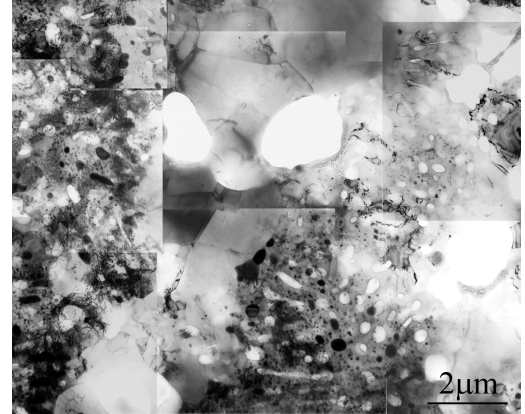

(b)

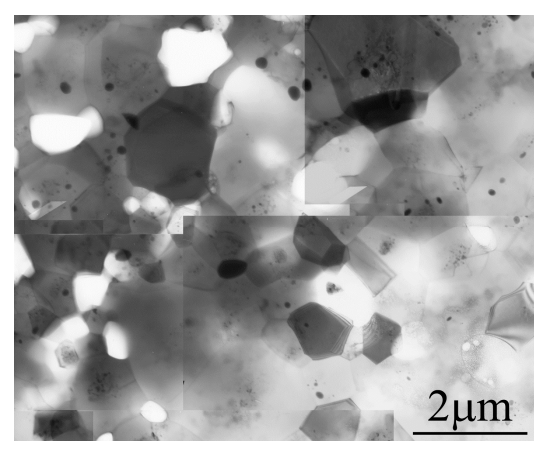

(c)

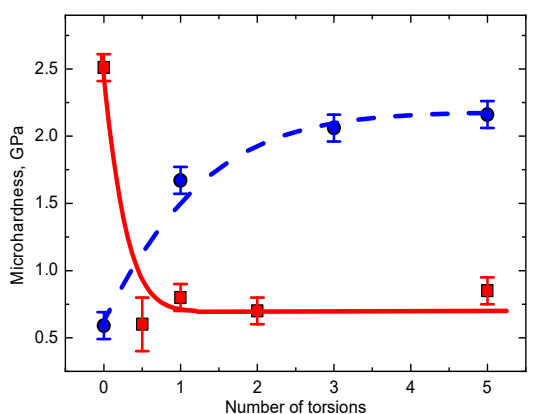

(e)

Figure 3. (a-d) Bright field transmission electron microscopy (TEM) micrographs of the Al-30\% $\mathrm{Zn}$ alloy in the initial state (a) and after HPT: $n=0$ (b), $n=0.5$ (c) and $n=5$ (d). (e) Vickers microhardness plotted vs. number of torsions for Al-30 wt.\% Zn (solid red squares) [8] and Al-8.8 wt.\% Mg alloys (solid blue circles) [25]. Reprinted with permission from ref. [8]. Copyright 2012 Elsevier. V.

The hardness and tensile strength also depend on the SPD mode and material, similar to the grain size. For example, if the purity of aluminium increases, then one can observe the transition from hardening to softening during HPT. Therefore, when the hardness of an alloy before SPD is higher than the steady-state value, then SPD would lead to its softening rather than its hardening [8]. Another example is the achievement of porosity saturation during the HPT of a powder material [74]. It is important to underline that different properties (torsion torque, grain size, resistivity [32], hardness, lattice parameter, etc.) do not reach the steady state simultaneously.

An interesting two-stage microhardness saturation can appear during composite deformation [75]. If the composite consists of two phases with different hardnesses, then the first steady state is reached when the microhardness of the softer phase saturates. If the shear stress (i.e., number of rotations in HPT) increases further, then the total microhardness increases again. It reaches the second steady state when the microhardness of harder phase saturates. The fact that the saturation in SPD is not always obvious can be due to similar inhomogeneities in the microstructure when different parts of the material reach the dynamic equilibrium at different effective strains.

Consider now the competition between dissolution and precipitation processes during HPT. In the steady state during HPT of a two-phase alloy containing the solid solution and precipitates of a second phase, a certain concentration in the solid solution $c_{\mathrm{ss}}$ is established. The $c_{\mathrm{ss}}$ value is controlled by the dynamic equilibrium between dissolution of a second phase and its precipitation. If the concentration in a solid solution $c_{\text {init }}$ before HPT is below $c_{\mathrm{ss}}, c_{\text {init }}<c_{\mathrm{sS}}$, it would increase, and precipitates would dissolve during HPT. In another case, if $c_{\text {init }}>c_{\mathrm{Ss}}$, then the concentration in a solid solution should decrease. As a result, the existing precipitates would grow (of new precipitates should form). This process is depicted as dynamic ageing [2]. 
The competition between the decomposition of the supersaturated solid solution and the dissolution of precipitates was investigated in $\mathrm{Cu}$-based alloys [2]. Physically, a certain steady-state concentration $c_{\mathrm{ss}}$ in the solid solution is reached during SPD. Indeed, when one needs to compare different binary alloys with various maximal solubilities $c_{\max }$ in a solid solution, the model of a so-called effective temperature $T_{\text {eff }}$ becomes quite useful. It means that after HPT, the concentration $c_{\mathrm{ss}}$ in a sample corresponds to an equilibrium solidus/solvus concentration at a certain elevated temperature $T_{\text {eff }}$.

As an example, we consider the $\mathrm{Cu}-\mathrm{Co}$ system [2]. The grains in the $\mathrm{Cu}$-based solid solution in the as cast $\mathrm{Cu}-4.9 \mathrm{wt}$ \% Co alloy were of 10-20 $\mu \mathrm{m}$ in size, finely dispersed cobalt precipitates were of about 10-20 nm in size, and cobalt particles were of about $2 \mu \mathrm{m}$ in size [2]. One sample was annealed at $1060{ }^{\circ} \mathrm{C}$ for $10 \mathrm{~h}$. Co fully dissolved in the Cu-based matrix, and the $(\mathrm{Cu})$ grain size grew in size to about $50 \mu \mathrm{m}$. Another sample was annealed at $570{ }^{\circ} \mathrm{C}$ for $840 \mathrm{~h}$. Here, the Cu-based solid solution almost fully decomposed and less than 0.5 wt.\%, and Co remained dissolved in Cu. After the HPT of both samples, the copper grain size decreased to $\sim 200 \mathrm{~nm}$, and the size of the Co-precipitates decreased to 10-20 nm (see micrographs in Figure 4). The lattice parameter of the sample annealed at $570{ }^{\circ} \mathrm{C}$ before HPT was almost equal to that of pure copper (diamond in Figure 4). With an increasing number of anvil rotations, the lattice parameter of sample annealed at $570{ }^{\circ} \mathrm{C}$ decreased, and that of sample annealed at $1060^{\circ} \mathrm{C}$ increased. After five anvil rotations, the lattice parameters in both samples became almost equal to each other and to that of the $(\mathrm{Cu})$ solid solution with about $2.5 \mathrm{wt}$ \% Co. The solid solution in both samples after HPT contained as much cobalt as if they would be annealed at $T_{\text {eff }}=900 \pm 30^{\circ} \mathrm{C}$ [2].

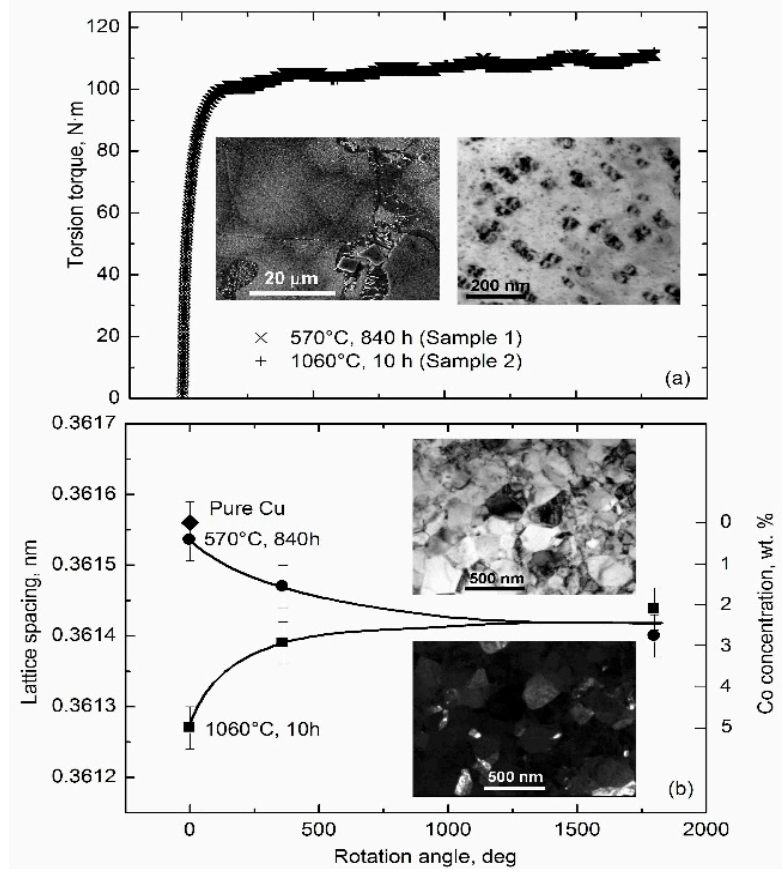

Figure 4. (a) Dependence of torsion torque on the HPT anvil rotation angle. The scanning electron microscopy (SEM, left) and transmission electron microscopy (TEM, right) micrographs in the insets are for the $\mathrm{Cu}-4.9 \mathrm{wt} . \% \mathrm{Co}$ alloy after annealing at $570{ }^{\circ} \mathrm{C}$ for $840 \mathrm{~h}$. (b) Dependence of lattice period on the HPT anvil rotation angle. Diamond shows the lattice period for pure copper. Circles mark the lattice period in sample annealed at $570{ }^{\circ} \mathrm{C}$ for $840 \mathrm{~h}$. Squares correspond to the sample annealed at $1060^{\circ} \mathrm{C}$ for $10 \mathrm{~h}$. The respective cobalt concentration is shown on the right vertical axis, $c_{\mathrm{eq}} \approx 2.5 \mathrm{wt} . \%$ Co. Insets: Bright-field (top) and dark-field (bottom) TEM micrographs of $\mathrm{Cu}-4.9$ wt.\% Co alloy after annealing at $570{ }^{\circ} \mathrm{C}$ for $840 \mathrm{~h}$ and $\mathrm{HPT}$ (6 GPa, $5 \mathrm{rot}, 1 \mathrm{rpm}$ ). Reprinted with permission from ref. [2]. Copyright 2014 Elsevier. 
In [76], the values of $T_{\text {eff }}$ are compared for several copper-based binaries, such as $\mathrm{Cu}-\mathrm{Co}$ [2], $\mathrm{Cu}-\mathrm{Ni}$ [77], $\mathrm{Cu}-\mathrm{In}, \mathrm{Cu}-\mathrm{Sn}$ [38], $\mathrm{Cu}-\mathrm{Ag}$ [39,40], $\mathrm{Cu}-\mathrm{Cr}, \mathrm{Cu}-\mathrm{Al}-\mathrm{Ni}$, and $\mathrm{Cu}-\mathrm{Hf}$. The value of $T_{\text {eff }}$ increases as the activation enthalpy increases for the bulk tracer diffusion $H_{\mathrm{D}}$ of a second component ( $\mathrm{Co}, \mathrm{Ni}, \mathrm{In}, \mathrm{Sn}, \mathrm{Ag}, \mathrm{Cr}, \mathrm{Al}$, or $\left.\mathrm{Hf}\right) . T_{\text {eff }}$ also linearly increases as the melting temperature $T_{\mathrm{m}}$ of $\mathrm{Co}, \mathrm{Ni}, \mathrm{In}, \mathrm{Sn}, \mathrm{Ag}, \mathrm{Cr}, \mathrm{Al}$, or $\mathrm{Hf}$ increases as well. This is due to the correlation between $H_{\mathrm{D}}$ and $T_{\mathrm{m}}$ of the diffusing alloying component.

In ref. [78], the competition between the dissolution and formation of precipitates during SPD was investigated using molecular dynamics simulations. The case for interacting alloy components has been studied. Key findings of this work are the nucleation and growth of precipitates during SPD at a temperature of $100 \mathrm{~K}$ and Gibbs-Thomson-like behaviour relating steady-state solubility to precipitate size under sustained shearing. The direct relationship between effective temperature and the shear modulus was observed. The importance of cluster agglomeration during precipitate growth was underlined. The simulations provided good semi-quantitative agreement with experimental findings reported in the literature. In ref. [39], another model describing the dynamic equilibrium between dissolution and precipitation during HPT was proposed. Assuming that HPT fixes the composition at matrix-precipitate interfaces, it has been shown that the HPTenhanced diffusive transport of species is the process that is likely controlling the observed steady-state composition in the matrix and the average diameter of the precipitates.

\section{Fragmentation of the Second Phase Particles}

If in the initial state, before the start of SPD, the sample is not single-phase, but consists of two or more phases, then with the onset of SPD, the fragmentation processes of particles in the second phase also starts. The most common variants of the initial structure of the material are (a) a mixture of powders of two phases, (b) a multilayer sample consisting of successive layers of two phases, and (c) compact samples in which the second phase is distributed in the form of particles in the volume or interlayers along the grain boundaries.

In [79], the fragmentation process in the W-Cu alloy was studied. In the W-Cu system, the solubility of $\mathrm{Cu}$ in $\mathrm{W}$ as well as the solubility of $\mathrm{W}$ in $\mathrm{Cu}$ is negligible. The $\mathrm{W}-25 \mathrm{wt} . \%$ $\mathrm{Cu}$ nano-composite was fabricated from a mixture of powders of two phases $\mathrm{Cu}$ and $\mathrm{W}$ with a grain size of $2-10 \mu \mathrm{m}$ using HPT. The samples were deformed at a pressure of $8 \mathrm{GPa}$, and they had a diameter $R$ of $8 \mathrm{~mm}$ and a thickness $t$ of $0.8 \mathrm{~mm}$. The number of turns $n$ was selected to attain a certain equivalent strain at a radius $r$ according to the relation $\varepsilon=1.15 \pi n r t^{-1}$. As a result, after 10 turns, the homogeneous microstructure with a $\mathrm{W}$ particle size of 10-20 nm was obtained [80]. Figure 5 demonstrates how the size of the $\mathrm{W}$ grains decreases and reaches the steady state value. We estimated the grain size of $W$ particles from the data published in ref. [81] and plotted it in Figure 6 against the number of HPT rotations $n$ (solid red squares). In [81], the same $\mathrm{W}-25 \mathrm{wt} . \% \mathrm{Cu}$ powders were deformed not only at room temperature but also at $200{ }^{\circ} \mathrm{C}$ and $400{ }^{\circ} \mathrm{C}$. The increase in the HPT temperature slows down the fragmentation process. This is because the rate of relaxation processes increases with increasing temperature, while the plastic deformation work achieved by the HPT tool remains approximately constant.

In [82-84], the fragmentation process was studied for the $\mathrm{Co}-\mathrm{Cu}$ alloys with 25,54 , and 75 at. $\%$ Co for $\mathrm{Co}-\mathrm{Cu}$ with small mutual solubility. At peritectic temperature, about 9 at.\% Co is solvable in $\mathrm{Cu}$, and about 12 at.\% $\mathrm{Cu}$ is solvable in Co. Similar to refs. [79,81], the starting state was the mixture of powders of the two phases of $\mathrm{Cu}$ and $\mathrm{Co}$, with a grain size of 2-10 $\mu \mathrm{m}$. The microhardness values saturated at $\varepsilon=\sim 100$ (about 4.5 turns). In Figure 6, the dependence of the Co grain size on number of turns is shown (solid red circles for $\mathrm{Cu}-54$ at.\% $\mathrm{Co}$ and solid red triangles for $\mathrm{Cu}-75$ at.\% Co). The fragmentation of the Co phase proceeds more slowly in the $\mathrm{Cu}-75$ at.\% Co alloy. This is easy to understand due to the higher strength of Co in comparison with $\mathrm{Cu}$. Recently, we observed the dissolution of about $2.5 \mathrm{at} \%$ Co in the copper matrix [2] during HPT. Through the HPT of $\mathrm{Cu}-\mathrm{Ag}$ alloys, not only silver dissolves in the copper matrix, but $\mathrm{Cu}$ also dissolves in $\mathrm{Ag}$ particles $[40,85]$. Therefore, one can suppose that during the HPT of mixture of $\mathrm{Cu}$ and 
Co powders in [82-84], the fragmentation also took place with the mutual dissolution of copper and cobalt. This could be the reason why the fragmentation process of $\mathrm{Co}-\mathrm{Cu}$ alloys goes slower in comparison to $\mathrm{W}-\mathrm{Cu}$ ones (see Figure 6).
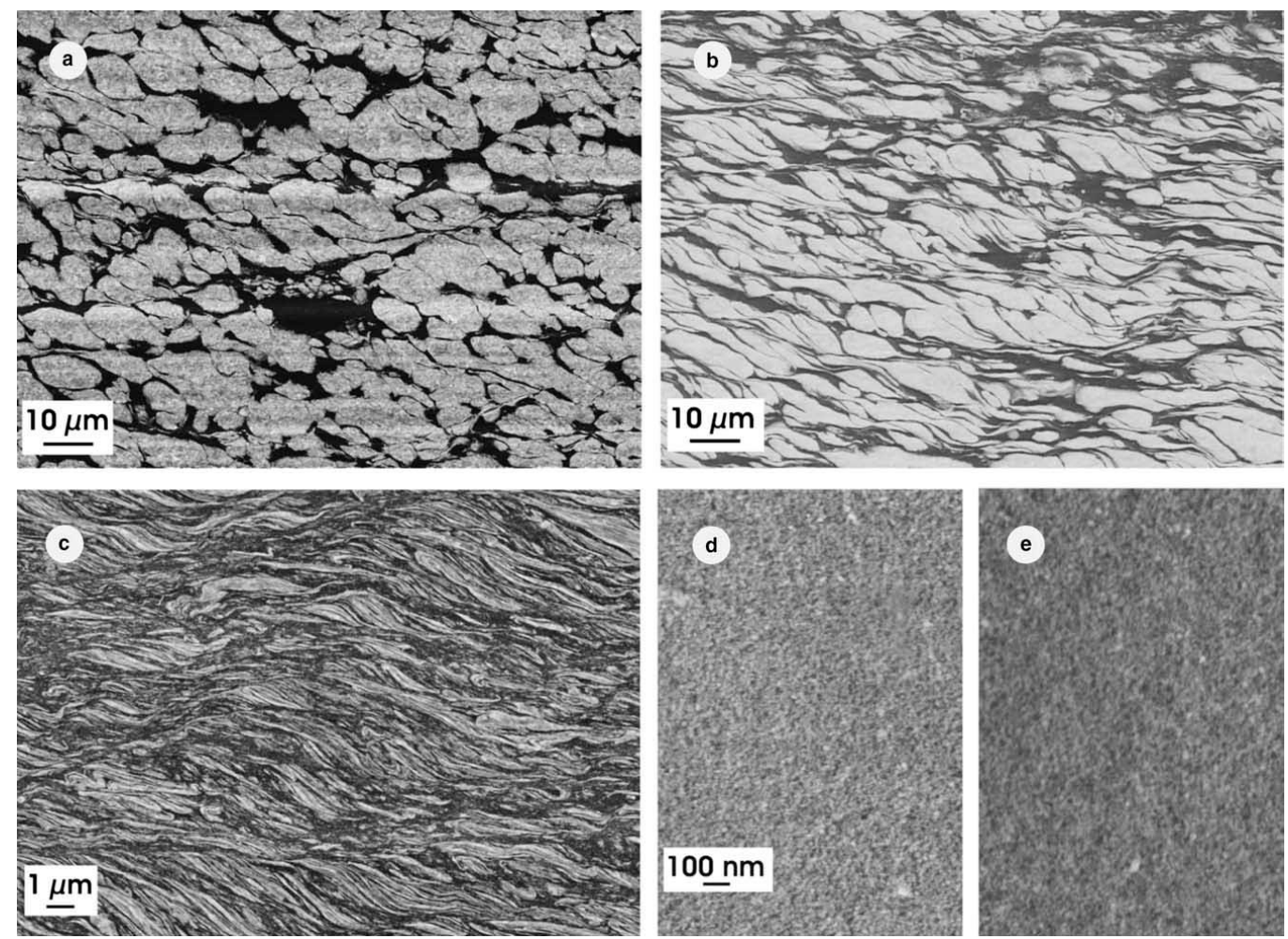

Figure 5. The microstructure of the $\mathrm{W}-25 \% \mathrm{Cu}$ composite subjected to $\mathrm{HPT}$ at room temperature to strains $\varepsilon$ of: (a) 4; (b) 16; (c) 64; (d) 256; (e) 512. Reprinted with permission from ref. [79]. Copyright 2005 Elsevier.

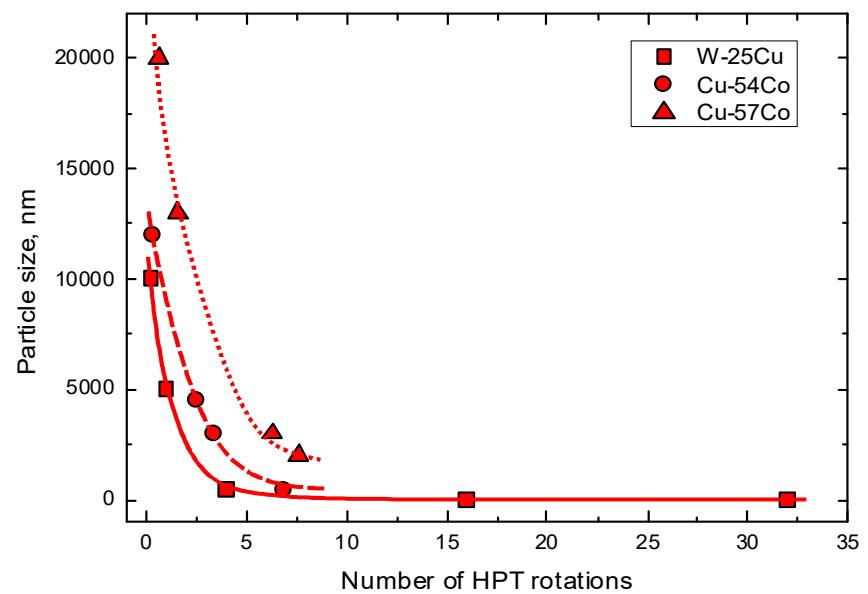

Figure 6. The dependence of particle size of on the number of HPT rotations. The size of W particles in the $\mathrm{W}-25 \mathrm{wt} . \% \mathrm{Cu}$ alloy (solid red squares) was estimated from the data published in ref. [81]. The size of Co particles in the $\mathrm{Cu}-54$ at.\% Co alloy (solid red circles) and $\mathrm{Cu}-75$ at.\% Co alloy (solid red triangles) was estimated from the data published in refs. [82,83]. The lines are the guides for the eye.

In ref. [86], a Cu/Ti bimetal nanocomposite was manufactured by accumulative rollbonding (ARB). In their original state, the commercially pure copper and titanium annealed sheets with an initial thickness of 300 and $100 \mu \mathrm{m}$, respectively, were scratch-brushed 
by a circular stainless steel brush. Afterwards, six $\mathrm{Cu}$ and five Ti strips were stacked alternatively together in an initial sandwich, with 22 vol.\% Ti having an overall thickness of $2.3 \mathrm{~mm}$. After that, it was roll-bonded to prepare a multilayered composite with a thickness of $1 \mathrm{~mm}$. This specimen was denominated as a first cycle ARB processed sample (Figure 7a). It is essential that the thickness reduction in this roll-bonding step is over $50 \%$. It guarantees the formation of acceptable bonding between the copper and titanium layers. The ARB process was then repeated up to nine cycles, with a $\sim 50 \%$ thickness reduction after each pass. During further ARB, the Ti layers break and form the elongated particles (see Figures 7 and 8).
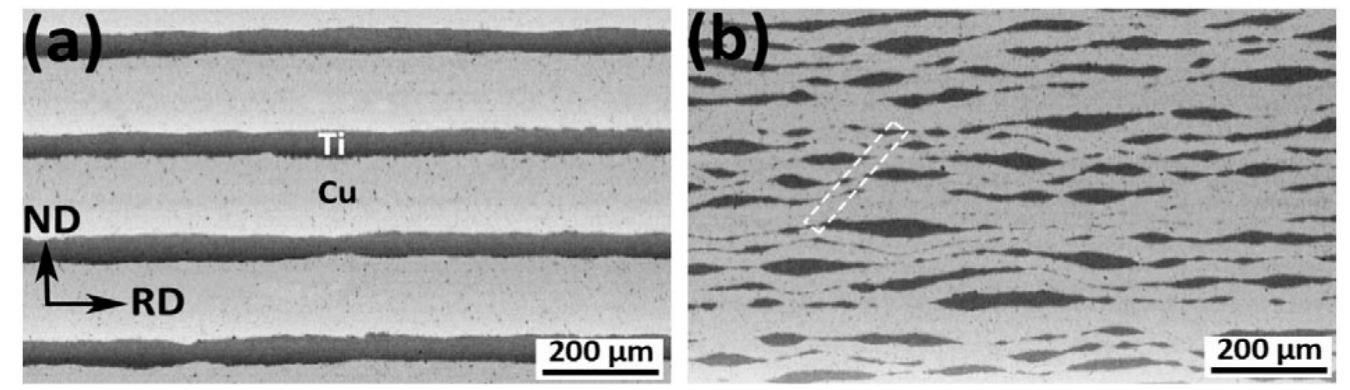

Figure 7. SEM micrographs of the ARB processed $\mathrm{Cu}$ /Ti bimetal composites after (a) 1 cycle, (b) after 3 cycles. Reprinted with permission from ref. [86]. Copyright 2017 Elsevier.
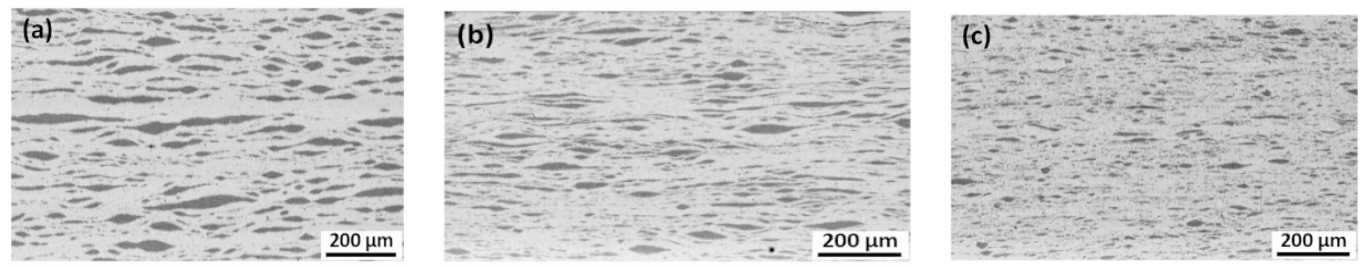

Figure 8. SEM micrographs of the ARB processed Cu/Ti bimetal composite after (a) 5 cycles, (b) 7 cycles, and (c) 9 cycles. Reprinted with permission from ref. [86]. Copyright 2017 Elsevier.

The model for the mechanical fragmentation of Ti layers has been proposed [86]. The fragmentation mechanism was described as follows: In the first ARB cycle, the presence of active crystallographic slip systems and the low density of dislocations in the annealed $\mathrm{Cu}$ and $\mathrm{Ti}$ structure result in the proper ductility and uniform deformation of both layers. However, with further processing, the dislocation density increases. An increase in the mechanical strength follows as well as a sharp decrease in ductility in comparison with materials after annealing. Such work-hardening by hindering in dislocation motion leads to the formation of shear bands (see Figure 9a). Such shear bands are the localized deformation zones. Consequently, the necking and fragmentation of Ti layers happen at these locations (see Figure 9b), where the geometrical softening overcomes the work hardening rate. In case of HPT, the fragmentation mechanism of the initial layered structure differs from that for ARB. In particular, the typical "torques" appear at a certain intermixing stage [16].

Figure 10a shows the dependence of mean thickness of Ti layers/fragments within the $\mathrm{Cu}$ matrix on the number of ARB cycles estimated from the data published in refs. [87-93] (see Figure 11). We see that the thickness of the Ti fragments obviously saturates and arrives at the steady-state value of about $2 \mu \mathrm{m}$. This value is much higher than the steady-state fragments size in $\mathrm{W}-\mathrm{Cu}$ and $\mathrm{Co}-\mathrm{Cu}$ alloys after HPT (see Figure 6). This is most likely due to the difference in mechanical conditions for the fragmentation between ARB and HPT processes. 
One can find important examples of second-phase fragmentation in the papers devoted to the SPD-driven fragmentation of cementite inside carbon steels $[60-65,87,88]$. The cementite plates are first broken, spheroidized, and in some cases, almost disappear. The newly formed grain boundaries (GBs) play an important role in this process. The amount of cementite decreases in the steel because the carbon forms the segregation layers in the new GBs during SPD-forced grain refinement [89]. These layers "consume" the carbon from cementite particles and decrease their volume fraction.

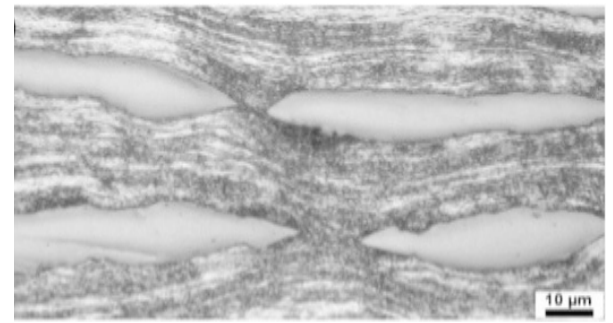

(a)

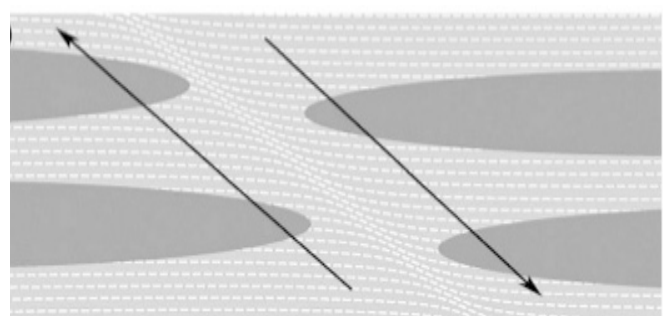

(b)

Figure 9. (a) Shear band formation within the composite after three ARB cycles. (b) Schematic illustration of segmentation mechanism at a shear band. Reprinted with permission from ref. [86]. Copyright 2017 Elsevier.

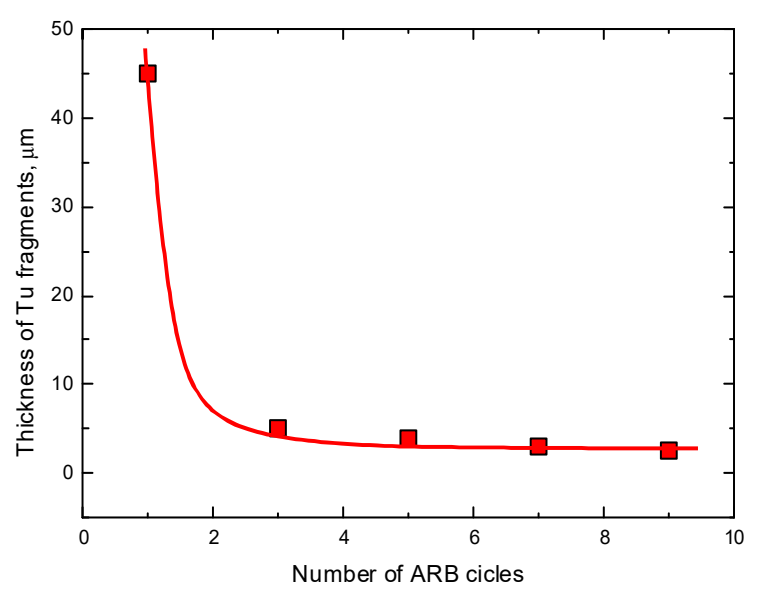

(a)

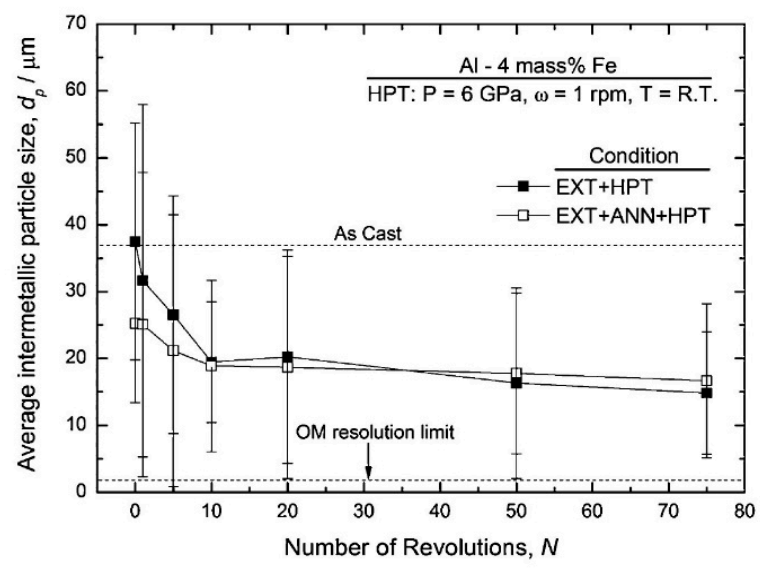

(b)

Figure 10. (a) Dependence of mean thickness of Ti layers/fragments within the $\mathrm{Cu}$ matrix on the number of ARB cycles estimated from the data published in refs. [87-93]. The lines are the guides for the eye. (b) The dependence of size $d$ of $\mathrm{Al}_{3} \mathrm{Fe}$ intermetallic particles in the $\mathrm{Al}-4 \mathrm{wt} . \% \mathrm{Fe}$ alloy on the number of HPT rotations $n . d(n)$ curves are shown for two cases, namely for the samples after extrusion and annealing followed by HPT (EXT + ANN + HPT, open squares) and for the alloys after extrusion followed by HPT (EXT + HPT, solid squares). Reprinted with permission from ref. [90]. Copyright 2012 Elsevier. 


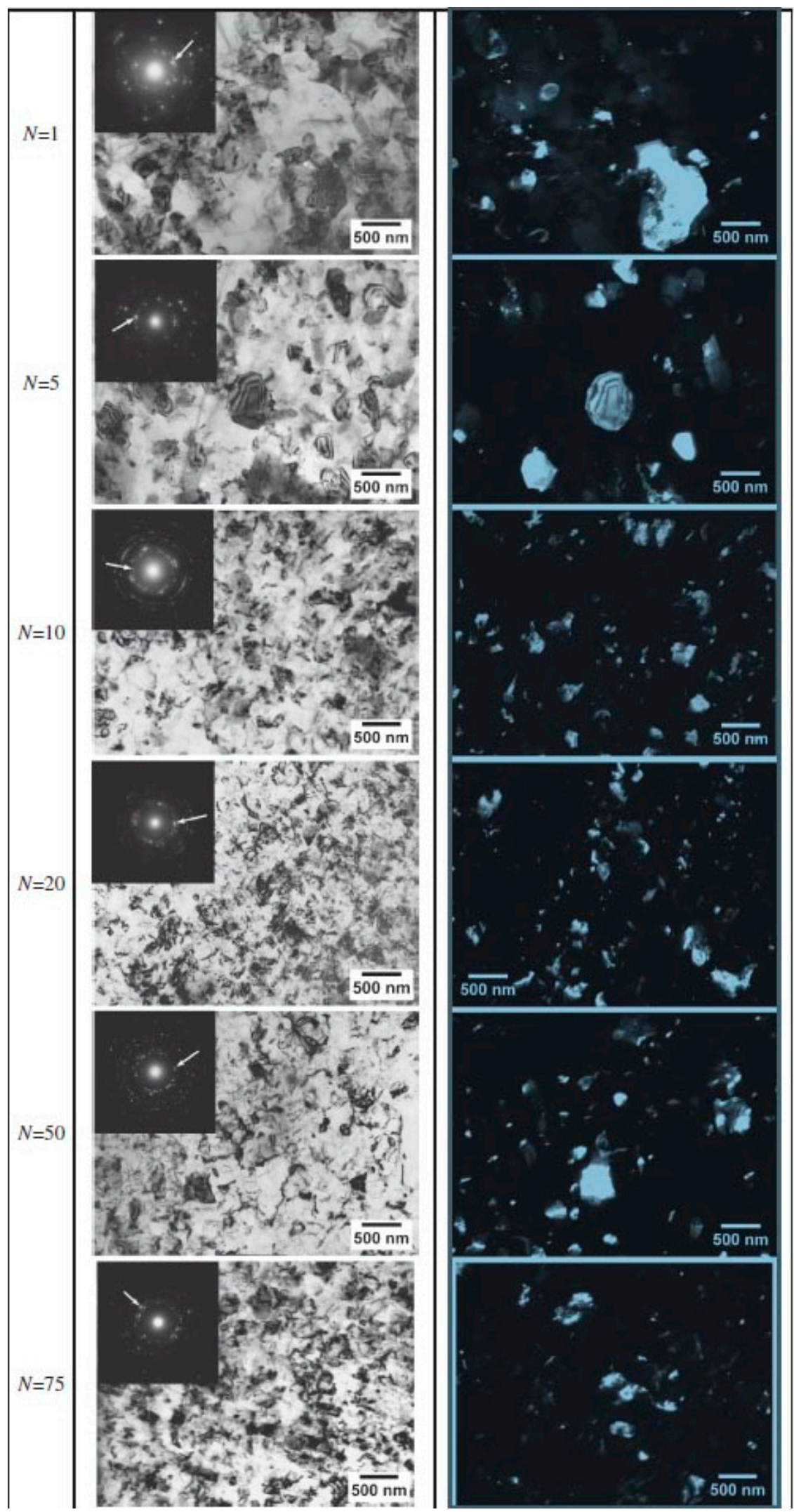

Figure 11. TEM micrographs showing $\mathrm{Al}-4 \% \mathrm{Fe}$ EXT + HPT microstructure evolution for different number of anvil rotations $n$. Dark field images obtained from diffracted beams indicated by arrows in corresponding SAED patterns (as insets in bright field images). Reprinted with permission from ref. [90]. Copyright 2012 Elsevier. 
In ref. [90], a bulk $\mathrm{Al}-4 \mathrm{wt}$ \% Fe alloy processed by extrusion or by a combination of extrusion (EXT) and successive annealing was subjected to HPT at $6 \mathrm{GPa}, 1 \mathrm{rpm}$, and for up to 75 plunger revolutions. After extrusion and successive annealing the samples contained the (Al) matrix (appears black in the dark-field TEM images, Figure 11) with $\mathrm{Al}_{3} \mathrm{Fe}$ intermetallic particles (appears bright in the dark-field TEM images, Figure 11). These $\mathrm{Al}_{3} \mathrm{Fe}$ particles continuously fragmented during HPT. The $\mathrm{Al}_{3} \mathrm{Fe}$ size saturates at $\sim 20 \mu \mathrm{m}$ after about 10 plunger revolutions and remains unchanged afterwards (Figure 10b). The Vickers microhardness also saturates but later, after about 20 plunger revolutions. The grain size in (Al) matrix is about $250 \mathrm{~nm}$, which is typical for the Al-based alloys after HPT. It reaches the saturation between one and five revolutions. Thus, the steady-state size of $\mathrm{Al}_{3} \mathrm{Fe}$ particles during HPT [90] is at least two orders of magnitude higher than that in $\mathrm{Cu}$ alloys with $\mathrm{W}, \mathrm{Co}$, and Ti after HPT and ARB [81-83,86]. This striking difference in fragmentation behavior can be attributed to a number of factors, such as different volume fractions of the particle phase, different hardness ratios between the particles and the matrix, and differences in the energies between the GBs and IBs. For example, in the W-Cu system, the $\mathrm{Cu}$ may wet the GBs in W, thus preventing the agglomeration of fragmented $\mathrm{W}$ particles.

The important point is, whether the composition or phases are changing in the particles during their fragmentation. The composition changes during SPD cannot be observed in the stoichiometric compounds (or daltonides) which exist in the very narrow composition interval [60-65,87-90]. In this case, only the portion of such compounds can be measured, and its possible change could be observed, such in the case of cementite in steels [89]. If the intermetallics exist in broad composition intervals (so-called bertollides), such as in the Hume-Rothery phases, such composition changes can be measured. However, some indications of the peak shift for the $\varepsilon$-phase in $\mathrm{Cu}-\mathrm{Sn}$ alloys can be found in the XRD diffraction patterns measured with synchrotron light before and after HPT [38]. The HPTdriven change of the composition was also observed in the silver particles distributed in the Cu-matrix [40]. Before HPT, the Cu-matrix was almost free from silver, and the silver particles also contained almost no copper. However, after HPT, a steady state was reached that was equivalent to the effective temperature $T_{\text {eff }}=600^{\circ} \mathrm{C}$. In other words, the silver concentration in the copper matrix as well as the copper content in the silver particles increased and reached values equal to the solubilities at $T_{\text {eff }}=600{ }^{\circ} \mathrm{C}$.

\section{Nanocrystallization of Amorphous Alloys and the Growth of Particles of the Second Phase}

In Section 2, we that in most cases, SPD leads to grain refinement in the material until the grain size drops to a certain steady-state value. However, in a number of experiments, it was possible to fabricate the original samples (before SPD) with a grain size smaller than the steady-state one. Then, the grain size, on the contrary, increased with the SPD until it reached the same stationary value (see Figure 2).

Unfortunately, at present, to the best of our knowledge, there are no observations of processes inverse to the fragmentation of second-phase particles. On the other hand, there are a number of studies in which there are no crystals at all in the initial state before SPD. In these studies, samples are subjected to SPD deformation in an amorphous state. This amorphous state is obtained using conventional amorphization technologies, such as rapid solidification. The data for the nanocrystallization during HPT of amorphous ribbons (AR), bulk amorphous alloys (BA), and helium gas atomized samples (He) are given in Table 1. 
Table 1. Nanocrystallization during HPT of amorphous ribbons (AR), bulk amorphous alloys (BA), and helium gas atomized sampl $(\mathrm{He})$.

\begin{tabular}{|c|c|c|c|c|c|}
\hline Alloy & $\begin{array}{c}\text { Grain Size of } \\
\text { Nanocrystals, } \mathrm{nm}\end{array}$ & $\begin{array}{c}\text { HPT Pressure } p, \\
\text { GPa }\end{array}$ & $\begin{array}{c}\text { Anvil Rotation } \\
\text { Rate, rpm }\end{array}$ & $\begin{array}{l}\text { Anvil Rotation } \\
\text { Number, } n\end{array}$ & Reference \\
\hline $\mathrm{Al}_{88} \mathrm{Y}_{7} \mathrm{Fe}_{5}$ & 12 & 6 & 1 & 5 & [91] AR \\
\hline $\mathrm{Al}_{85} \mathrm{Y}_{8} \mathrm{Ni}_{5} \mathrm{Co}_{2}$ & fcc $\mathrm{Al}, 13$ & 6 & 1 & 5 & [92] AR \\
\hline $\mathrm{Al}_{90} \mathrm{Y}_{10}$ & 7 & 5 & 1 & 5 & [93] AR \\
\hline $\mathrm{Al}_{90} \mathrm{Y}_{10}$ & 10 & 5 & 1 & $0.1,2$ & [94] AR \\
\hline $\mathrm{Al}_{85} \mathrm{Ce}_{8} \mathrm{Ni}_{5} \mathrm{Co}_{2}$ & 19 & 6 & 1 & 5 & {$[95,96] \mathrm{AR}$} \\
\hline $\mathrm{Fe}_{78} \mathrm{Si}_{13} \mathrm{~B}_{9}$ & 6 & 4 & 1 & 5 & [97] AR \\
\hline $\mathrm{Nd}_{9} \mathrm{Fe}_{85} \mathrm{~B}_{6}$ & $<10$ & 6 & 1 & 5 & {$[98,99] \mathrm{AR}$} \\
\hline $\mathrm{Cu}_{60} \mathrm{Zr}_{20} \mathrm{Ti}_{20}$ & $<20$ & 6 & 1 & 5 & [100] AR \\
\hline $\mathrm{Ti}_{50} \mathrm{Ni}_{25} \mathrm{Cu}_{25}$ & $\sim 20, T=20^{\circ} \mathrm{C}$ & 6 & 1 & 10 & [101] AR \\
\hline $\mathrm{Ti}_{50} \mathrm{Ni}_{25} \mathrm{Cu}_{25}$ & $\sim 20, T=150^{\circ} \mathrm{C}$ & 6 & 1 & 10 & [102] AR \\
\hline $\mathrm{Ti}_{50} \mathrm{Ni}_{20} \mathrm{Cu}_{30}$ & $\sim 20-100$ & 6 & 1 & $1,3,5$ & \\
\hline $\begin{array}{c}\text { Vitreloy } \\
\mathrm{Zr}_{44} \mathrm{Ti}_{11} \mathrm{Cu}_{10} \mathrm{Ni}_{10} \mathrm{Be}_{25}\end{array}$ & $10, T=610,620,630 \mathrm{~K}$ & 8 & 0.2 & 1 & [103] BA \\
\hline $\mathrm{Zr}_{65} \mathrm{Cu}_{17} \mathrm{Ni}_{5} \mathrm{Al}_{10} \mathrm{Au}_{3}$ & 50 & 5 & 2 & 1 & [104] BA \\
\hline $\mathrm{Al}_{85} \mathrm{Ni}_{10} \mathrm{La}_{5}$ & 10 & 6 & 0.3 & 1 & [105] He \\
\hline
\end{tabular}

Thus, in the majority of cases, the nanocrystallization was only investigated for one strain value (most frequently equivalent to $n=5$ ). However, there are at least three examples where the nanocrystallization was studied for several strain values. In the first case, the $\mathrm{Fe}_{53.3} \mathrm{Ni}_{26.5} \mathrm{~B}_{20.2}$ and $\mathrm{Co}_{28.2} \mathrm{Fe}_{38.9} \mathrm{Cr}_{15.4} \mathrm{Si}_{0.3} \mathrm{~B}_{17.2}$ (at. \%) $25 \mu \mathrm{m}$ thick amorphous ribbons quenched from the melt were studied [106]. The compacted disks made of these ribbons were subjected to HPT at $6 \mathrm{GPa}$ with a rotation rate of $1 \mathrm{rpm}$ for 0.5 to 9 anvil rotations. At the beginning, the samples were completely amorphous, i.e., the size of the crystals was zero. Then, during HPT, the nanograins belonging to the crystalline phase started to nucleate in amorphous matrix (Figure 12). In Figure 13a, the size of the nanocrystals in the $\mathrm{Co}_{28.2} \mathrm{Fe}_{38.9} \mathrm{Cr}_{15.4} \mathrm{Si}_{0.3} \mathrm{~B}_{17.2}$ alloy estimated from the data published in ref. [106] is plotted against rotation number $n$. First, the nanocrystals appeared already after 1 rotation, then the size of the nanocrystals increased and saturated at $\sim 25 \mathrm{~nm}$ after about six anvil rotations. In the $\mathrm{Fe}_{53.3} \mathrm{Ni}_{26.5} \mathrm{~B}_{20.2}$ and alloy of the first nanocrystals appeared after three rotations, and their size saturated at about $40 \mathrm{~nm}$ (see Figure 11). When the size of the nanocrystals saturated, their amount continued to increase (compare number of bright spots in SAED patterns in Figure 12a,b) [106].
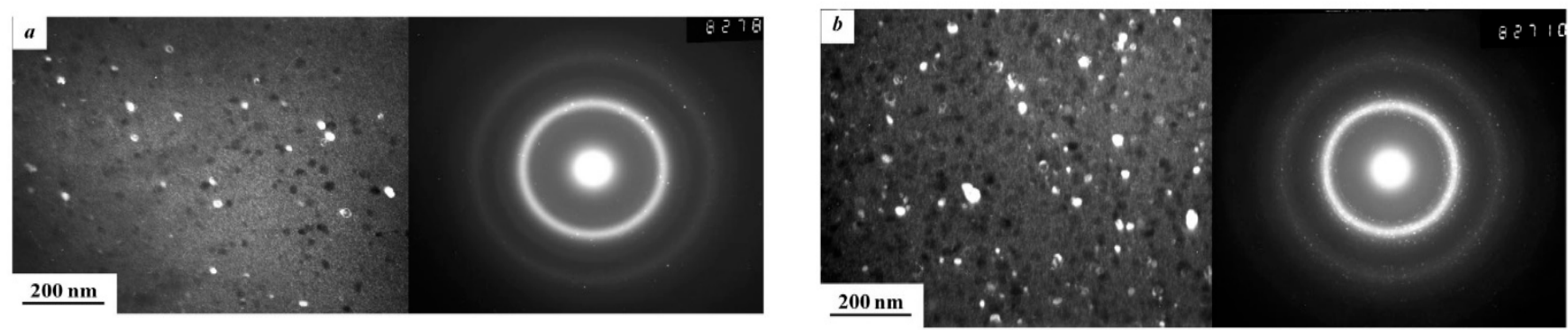

Figure 12. Dark-field images of the $\mathrm{Fe}_{53.3} \mathrm{Ni}_{26.5} \mathrm{~B}_{20.2}$ amorphous ribbons structure subjected to HPT to $n=3$ (a) and $n=9$ (b) and the corresponding selected area electron diffraction (SAED) patterns. Reprinted with permission from ref. [106]. Copyright 2020 MDPI. 

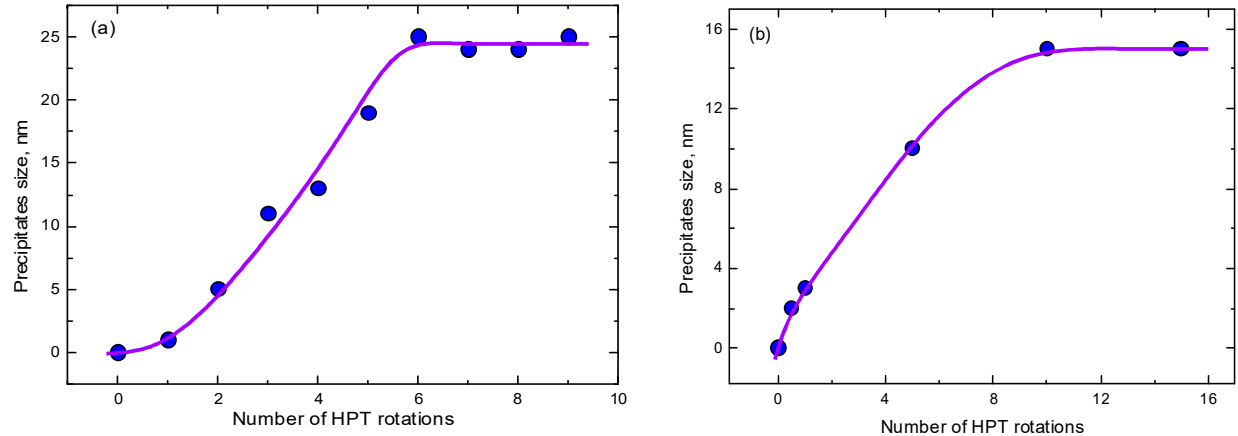

Figure 13. The dependence of size of nanocrystals (a) in the $\mathrm{Fe}_{53.3} \mathrm{Ni}_{26.5} \mathrm{~B}_{20.2}$ amorphous alloy estimated from the data published in ref. [106] and (b) in the $\mathrm{Ti}_{50} \mathrm{Ni}_{25} \mathrm{Cu}_{25}$ amorphous alloy estimated from the data published in refs. $[107,108]$ on the number of HPT rotations. The lines are the guides for the eye.

In Refs. $[107,108]$, the $\mathrm{Ti}_{50} \mathrm{Ni}_{25} \mathrm{Cu}_{25}$ amorphous alloy obtained by the melt spinning were studied. Its HPT took place at $7 \mathrm{GPa}, 1 \mathrm{rpm}$ with $n=0.5,1,5,10$, and 15 anvil rotations. The first nanocrystals had already appeared after $n=0.5$. They are not equiaxial as in [106] but elongated. In Figure 13b, the thickness of the nanocrystals in the $\mathrm{Ti}_{50} \mathrm{Ni}_{25} \mathrm{Cu}_{25}$ alloy estimated from the data published in refs. $[107,108]$ is plotted against rotations number $n$. The size of these nanograins of B2 phase crystallized from the amorphous matrix under the action of HPT saturated at about $15 \mathrm{~nm}$.

In Refs. [93,94], the HPT of amorphous ribbons of $\mathrm{Al}_{90} \mathrm{Y}_{10}$ alloy was studied for $p=5 \mathrm{GPa}, 1 \mathrm{rpm}, n=0.1,0.5,1,2$ and 5 . The extremely fine Al particles crystallized in the amorphous matrix (see TEM micrographs in Figure 14). First, the Al nanocrystals are visible even after 0.1 plunger revolutions (Figure 14a). Moreover, their size had already saturated at $\sim 9 \mathrm{~nm}$ after 1 plunger revolution (Figure 15).
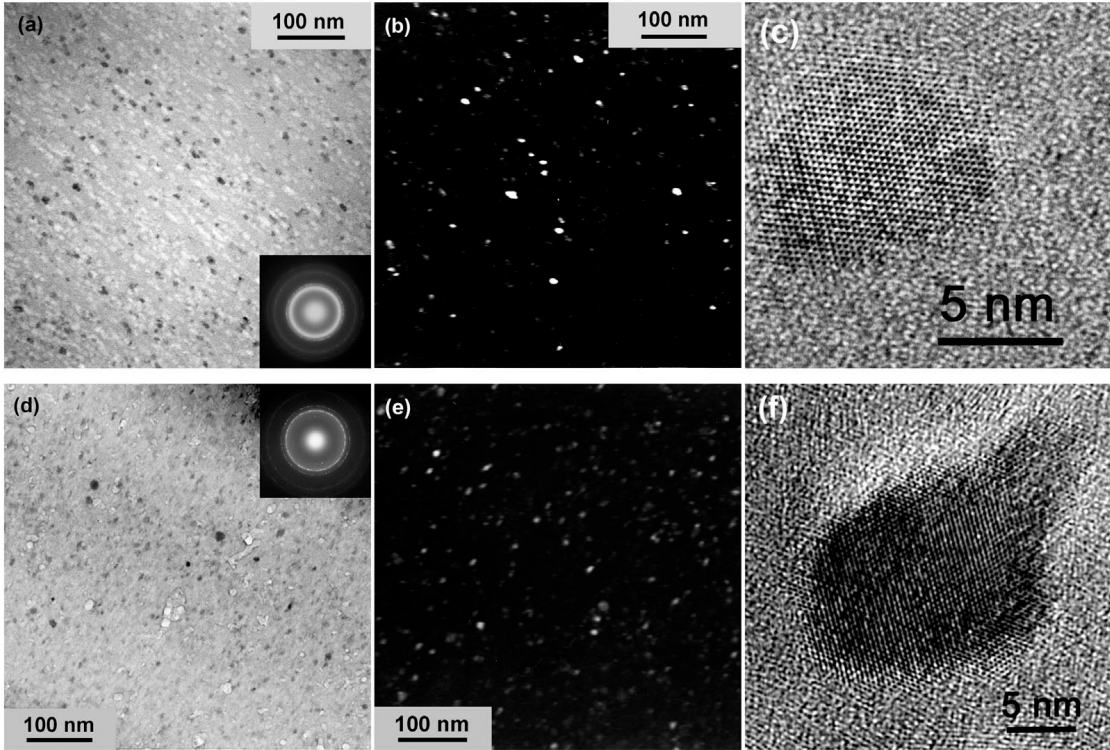

Figure 14. Microstructure of the $\mathrm{Al}_{90} \mathrm{Y}_{10}$ alloy subjected to deformation at $n=0.1(\mathbf{a}-\mathbf{c})$ and $n=2$ $(\mathbf{d}-\mathbf{f})$. (a,d)-BF images, (b,e)—DF images, inserts—corresponding SAED patterns, $(\mathbf{c}, \mathbf{f})$ - HRTEM images of individual $\mathrm{Al}$ crystals having formed after deformation. Reprinted with permission from ref. [94]. Copyright 2017 Elsevier. 


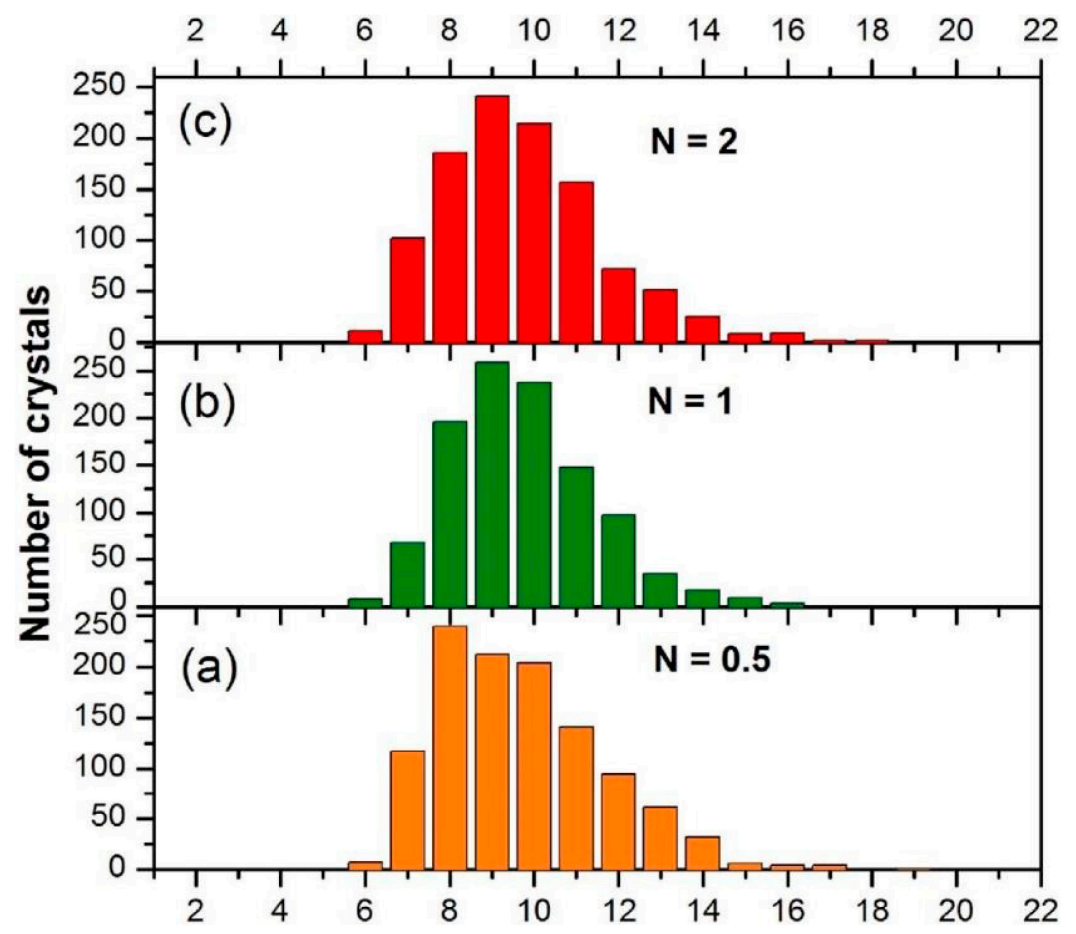

Figure 15. Size distribution for $\mathrm{Al}_{90} \mathrm{Y}_{10}$ alloy subjected to HPT at the strain corresponding to (a) $n=0.5$, (b) $n=1$, and (c) $n=2$. Reprinted with permission from ref. [94]. Copyright 2017 Elsevier.

The formation of nanocrystals from an amorphous matrix during HPT has another important aspect in addition to the size of these nanocrystals. When studying the competition between decomposition and formation of solid solutions during HPT, we found that the composition of the solid solution converges to a certain stationary value of $c_{\mathrm{sS}}[2,41]$. This steady-state value is the same as in solid solutions equilibrated at a certain elevated temperature. This temperature is commonly called the effective temperature $T_{\text {eff }}$. Apparently, a certain physical meaning is hidden behind the formal similarity of the concentration in the solid solution at HPT and the concentration in the solid solution after annealing at the effective temperature $T_{\text {eff }}$. In other words, under severe external action, a certain increased steady-state concentration of lattice defects is formed. This increased concentration of lattice defects is similar, for example, to a high vacancy concentration at an elevated temperature $T_{\text {eff }}$. Moreover, we found that the value of the effective temperature in copper alloys is proportional to the height of the energy barrier for bulk diffusion in these alloys. This means that the higher the energy barrier for diffusional mass transfer, the slower the relaxation of defects arising during deformation, and the higher the steady-state concentration of excess defects, and hence the effective temperature $T_{\text {eff }}$. The value of $T_{\text {eff }}$ can be determined not only from the value of the concentration in the solid solution, but also from the temperature range of the existence of certain intermetallic phases. Such a possibility also exists during nanocrystallization analysis.

For example, in refs. $[98,109,110]$, the amorphous alloy $\mathrm{Al}_{85} \mathrm{Ce}_{8} \mathrm{Ni}_{5} \mathrm{Co}_{2}$ was subjected to three types of processing: equilibrium annealing, high pressure torsion, and ball milling. Ball milling leads to the formation of a mixture of $\alpha-\mathrm{Al}$ and $\mathrm{Al}_{11} \mathrm{Ce}_{3}$ phases. This is equivalent to the annealing at $T_{\text {eff }}=\sim 560 \mathrm{~K}$. During HPT, only the $\alpha$-Al phase was formed in the alloys. This is equivalent to the annealing in the temperature range $535-543 \mathrm{~K}$. Thus, the effective temperature for HPT, which can be determined from the data on nanocrystallization in the $\mathrm{Al}_{85} \mathrm{Ce}_{8} \mathrm{Ni}_{5} \mathrm{Co}_{2}$ alloy, is approximately $T_{\text {eff }}=540 \mathrm{~K}$. It is below the $T_{\text {eff }}$ for ball milling. This fact correlates with the data shown in Figure 1, which indicates that the steady-state grain size for ball milling is lower that the steady-state grain size for HPT. In other words, the steady-state concentration of excess defects is higher for ball milling compared to HPT. 


\section{Conclusions}

1. The various SPD methods lead to the steady state microstructure and properties after certain strain value. This is because of the dynamic equilibrium between the deformation and relaxation processes.

2. The steady state of different properties is achieved at different strain values and can be reached both "from the top" and "from the bottom". We briefly discussed the examples of well-known steady state for torsion torque at HPT, grain size, microhardness, and concentration in solid solution.

3. The main topic of this review was, however, the possible competition between the fragmentation of second phase particles and their growth. The direct experimental observations of competition between fragmentation and growth are still absent. Therefore, we compared the decrease in the second phase particles during HPT and ARB (as "from the top" process) with the growth on nanocrystals in the amorphous matrix (as "from the bottom" process).

4. It looks like the saturation value of particle size depends on their hardness and volume fraction. The hard and brittle particles remain (or become) bigger than the soft and deformable ones. Certainly, the main fragmentation mechanism is the mechanical rupture by the shear bands crossing the particles. In the presence of mutual solubility, the mechanism of competing dissolution/precipitation also influences the fragmentation/growth process.

Author Contributions: Conceptualization, B.B.S. and R.K.; methodology, R.K. and P.B.S.; formal analysis, L.K., P.B.S. and E.R.; writing-original draft preparation, B.B.S. and R.K.; writing-review and editing, B.B.S., R.K. and E.R.; supervision, B.B.S. and B.B.; project administration, B.B.S., B.B., R.K., and O.A.K.; funding acquisition, B.B.S., R.K. and B.B. All authors have read and agreed to the published version of the manuscript.

Funding: This research was funded by the Russian Ministry of Science and Higher Education (contract no. 075-15-2021-999 grant no. 13.2251.21.0058).

Institutional Review Board Statement: Not applicable.

Informed Consent Statement: Not applicable.

Data Availability Statement: Data are contained within the article.

Acknowledgments: We acknowledge the support by the KIT-Publication Fund of the Karlsruhe Institute of Technology. Support from the Volkswagen Foundation through the Cooperation Project Az.:97 751 is also acknowledged.

Conflicts of Interest: The authors declare no conflict of interest. The funders had no role in the design of the study; in the collection, analyses, or interpretation of data; in the writing of the manuscript; or in the decision to publish the results.

\section{References}

1. Azabou, M.; Makhlouf, T.; Saurin, J.; Escoda, L.; Suñol, J.J.; Khitouni, M. A study of densification and phase transformations of nanocomposite $\mathrm{Cu}-\mathrm{Fe}$ prepared by mechanical alloying and consolidation process. Int. J. Adv. Manuf. Technol. 2016, 87, 981-987. [CrossRef]

2. Straumal, B.; Kilmametov, A.R.; Kucheev, Y.O.; Kurmanaeva, L.; Ivanisenko, Yu.; Baretzky, B.; Korneva, A.; Zięba, P.; Molodov, D.A. Phase transitions during high pressure torsion of $\mathrm{Cu}-\mathrm{Co}$ alloys. Mater. Lett. 2014, 118, 111-114. [CrossRef]

3. Huang, Y.; Sabbaghianrad, S.; Almazrouee, A.I.; Al-Fadhalah, K.J.; Alhajeri, S.N.; Langdon, T.G. The significance of self-annealing at room temperature in high purity copper processed by high-pressure torsion. Mater. Sci. Eng. A 2016, 656, 55-66. [CrossRef]

4. Lugo, N.; Llorca, N.; Cabrera, J.M.; Horita, Z. Microstructures and mechanical properties of pure copper deformed severely by equal-channel angular pressing and high pressure torsion. Mater. Sci. Eng. A 2008, 477, 366-371. [CrossRef]

5. Č́̌žek, J.; Janeček, M.; Srba, O.; Kužel, R.; Barnovská, Z.; Procházka, I.; Dobatkin, S. Evolution of defects in copper deformed by high-pressure torsion. Acta Mater. 2011, 59, 2322-2329. [CrossRef]

6. $\quad$ Liao, X.Z.; Zhao, Y.H.; Zhu, Y.T.; Valiev, R.Z.; Gunderov, D.V. Grain-size effect on the deformation mechanisms of nanostructured copper processed by high-pressure torsion. J. Appl. Phys. 2004, 96, 636-640. [CrossRef] 
7. Straumal, B.B.; Protasova, S.G.; Mazilkin, A.A.; Baretzky, B.; Goll, D.; Gunderov, D.V.; Valiev, R.Z. Effect of severe plastic deformation on the coercivity of Co-Cu alloys. Phil. Mag. Lett. 2009, 89, 649-654. [CrossRef]

8. Shamsborhan, M.; Ebrahimi, M. Production of nanostructure copper by planar twist channel angular extrusion process. J. Alloys Comp. 2016, 682, 552-556. [CrossRef]

9. Tang, C.L.; Li, H.; Li, S.Y. Effect of processing route on grain refinement in pure copper processed by equal channel angular extrusion. Trans. Nonferr. Met. Soc. China 2016, 26, 1736-1744. [CrossRef]

10. Mao, Z.N.; Gu, R.C.; Liu, F.; Liu, Y.; Liao, X.Z.; Wang, J.T. Effect of equal channel angular pressing on the thermal-annealinginduced microstructure and texture evolution of cold-rolled copper. Mater. Sci. Eng. A 2016, 674, 186-192. [CrossRef]

11. Bagherpour, E.; Qods, F.; Ebrahimi, R.; Miyamoto, H. Microstructure quantification of ultrafine grained pure copper fabricated by simple shear extrusion (SSE) technique. Mater. Sci. Eng. A 2016, 674, 221-231. [CrossRef]

12. Bagherpour, E.; Qods, F.; Ebrahimi, R.; Miyamoto, H. Microstructure evolution of pure copper during a single pass of simple shear extrusion (SSE): Role of shear reversal. Mater. Sci. Eng. A 2016, 666, 324-338. [CrossRef]

13. Yadav, P.C.; Sinhal, A.; Sahu, S.; Roy, A.; Shekhar, S. Microstructural inhomogeneity in constrained groove pressed Cu-Zn alloy sheet. J. Mater. Eng. Perform. 2016, 25, 2604-2614. [CrossRef]

14. Bryła, K.; Morgiel, J.; Faryna, M.; Edalati, K.; Horita, Z. Effect of high-pressure torsion on grain refinement, strength enhancement and uniform ductility of EZ magnesium alloy. Mater. Lett. 2018, 212, 323-326. [CrossRef]

15. Sadasivan, N.; Balasubramanian, M.; Venkatesh, R.; Vigneshram, S.; Sunil, T. Influence of equal channel angular pressing in an acute angle die with a back pressure notch on grain refinement, torsion and mechanical properties of aluminium (Einfluss des Equal Channel Angular Pressens in einer spitzwinkligen Matrize mit Rückdruckstufe auf Kornverfeinerung, Torsion und mechanische Eigenschaften von Aluminium). Mater. Sci. Eng. Technol. 2019, 50, 155-164. [CrossRef]

16. Kulagin, R.; Beygelzimer, Y.; Ivanisenko, Y.; Mazilkin, A.; Straumal, B.; Hahn, H. Instabilities of interfaces between dissimilar metals induced by high pressure torsion. Mater. Lett. 2018, 222, 172-175. [CrossRef]

17. Valiev, R.Z.; Islamgaliev, R.K.; Alexandrov, I.V. Bulk nanostructured materials from severe plastic deformation. Progr. Mater. Sci. 2000, 45, 103-189. [CrossRef]

18. Bryła, K.; Krystian, M.; Horky, J.; Mingler, B.; Mroczka, K.; Kurtyka, P.; Lityńska-Dobrzyńska, L. Improvement of strength and ductility of an EZ magnesium alloy by applying two different ECAP concepts to processable initial states. Mater. Sci. Eng. A 2018, 737, 318-327. [CrossRef]

19. Lukyanova, E.A.; Martynenko, N.S.; Serebryany, V.N.; Belyakov, A.N.; Rokhlin, L.L.; Dobatkin, S.V.; Estrin, Y.Z. Structure and mechanical and corrosion properties of a magnesium $\mathrm{Mg}-\mathrm{Y}-\mathrm{Nd}-\mathrm{Zr}$ alloy after high pressure torsion. Russ. Metall. (Metally) 2017, 2017, 912-921. [CrossRef]

20. Krala, P.; Dvorak, J.; Sklenicka, V.; Masuda, T.; Horita, Z.; Kucharova, K.; Kvapilova, M.; Svobodova, M. Microstructure and creep behaviour of P92 steel after HPT. Mater. Sci. Eng. A 2018, 723, 287-295. [CrossRef]

21. Sabbaghianrad, S.; Torbati-Sarraf, S.A.; Langdon, T.G. An investigation of the limits of grain refinement after processing by a combination of severe plastic deformation techniques: A comparison of $\mathrm{Al}$ and $\mathrm{Mg}$ alloys. Mater. Sci. Eng. A 2018, 712, 373-379. [CrossRef]

22. Tirsatine, K.; Azzeddine, H.; Huang, Y.; Baudin, T.; Helbert, A.-L.; Brisset, F.; Bradai, D.; Langdon, T.G. An EBSD analysis of Fe-36\%Ni alloy processed by HPT at ambient and a warm temperature. J. Alloys Comp. 2018, 753, 46-53. [CrossRef]

23. Alawadhi, M.Y.; Sabbaghianrad, S.; Huang, Y.; Langdon, T.G. Direct influence of recovery behaviour on mechanical properties in oxygen-free copper processed using different SPD techniques: HPT and ECAP. J. Mater. Res. Technol. 2017, 6, 369-377. [CrossRef]

24. Lee, S.; Horita, Z. High-pressure torsion for pure chromium and niobium. Mater. Trans. 2012, 53, 38-45. [CrossRef]

25. Edalati, K.; Akama, D.; Nishio, A.; Lee, S.; Yonenaga, Y.; Cubero-Sesin, J.M.; Horita, Z. Influence of dislocation-solute atom interactions and stacking fault energy on grain size of single-phase alloys after severe plastic deformation using high-pressure torsion. Acta Mater. 2014, 69, 68-77. [CrossRef]

26. Tejedor, R.; Edalati, K.; Benito, J.A.; Horita, Z.; Cabrera, J.M. High-pressure torsion of iron with various purity levels and validation of Hall-Petch strengthening mechanism. Mater. Sci. Eng. A 2019, 743, 597-605. [CrossRef]

27. Mohamed, I.F.; Masuda, T.; Lee, S.; Edalati, K.; Horita, Z.; Hirosawa, S.; Matsuda, K.; Terada, D.; Omar, M.Z. Strengthening of A2024 alloy by high-pressure torsion and subsequent aging. Mater. Sci. Eng. A 2017, 704, 112-118. [CrossRef]

28. Edalati, K.; Shao, H.; Emami, H.; Iwaoka, H.; Akiba, E.; Horita, Z. Activation of titanium-vanadium alloy for hydrogen storage by introduction of nanograins and edge dislocations using high-pressure torsion. Int. J. Hydr. Ener. 2016, 41, 8917-8924. [CrossRef]

29. Isik, M.; Niinomi, M.; Cho, K.; Nakai, M.; Liu, H.; Yilmazer, H.; Horita, Z.; Sato, S.; Narushima, T. Microstructural evolution and mechanical properties of biomedical Co-Cr-Mo alloy subjected to high-pressure torsion. J. Mech. Bech. Biomed. Mater. 2016, 59, 226-235. [CrossRef]

30. Isik, M.; Niinomi, M.; Liu, H.; Cho, K.; Nakai, M.; Horita, Z.; Sato, S.; Narushima, T.; Yilmazer, H.; Nagasako, M. Grain refinement mechanism and evolution of dislocation structure of $\mathrm{Co}-\mathrm{Cr}-\mathrm{Mo}$ alloy subjected to high-pressure torsion. Mater. Trans. 2016, 57, 1109-1118. [CrossRef]

31. Hongo, T.; Edalati, K.; Iwaoka, H.; Arita, M.; Matsuda, J.; Akiba, E.; Horita, Z. High-pressure torsion of palladium: Hydrogeninduced softening and plasticity in ultrafine grains and hydrogen-induced hardening and embrittlement in coarse grains. Mater. Sci. Eng. A 2014, 618, 1-8. [CrossRef] 
32. Edalati, K.; Imamura, K.; Kiss, T.; Horita, Z. Equal-channel angular pressing and high-pressure torsion of pure copper: Evolution of electrical conductivity and hardness with strain. Mater. Trans. 2012, 53, 123-127. [CrossRef]

33. Hanna, A.; Azzeddine, H.; Lachha, R.; Baudin, T.; Helbert, A.-L.; Brisset, F.; Huang, Y.; Bradai, D.; Langdon, T.G. Evaluating the textural and mechanical properties of an Mg-Dy alloy processed by high-pressure torsion. J. Alloys Comp. 2019, 778, 61-71. [CrossRef]

34. Bourezg, Y.I.; Azzeddine, H.; Baudin, T.; Helbert, A.-L.; Huang, Y.; Bradai, D.; Langdon, T.G. Texture and microhardness of Mg-rare earth (Nd and $\mathrm{Ce}$ ) alloys processed by high-pressure torsion. Mater. Sci. Eng. A 2018, 724, 477-485. [CrossRef]

35. Bazarnik, P.; Huang, Y.; Lewandowska, M.; Langdon, T.G. Enhanced grain refinement and microhardness by hybrid processing using hydrostatic extrusion and high-pressure torsion. Mater. Sci. Eng. A 2018, 712, 513-520. [CrossRef]

36. Cardona, D.M.M.; Wongsa-Ngam, J.; Jimenez, H.; Langdon, T.G. Effects on hardness and microstructure of AISI 1020 low-carbon steel processed by high-pressure torsion. J. Mater. Res. Technol. 2017, 6, 355-360. [CrossRef]

37. Torbati-Sarraf, S.A.; Sabbaghianrad, S.; Figueiredo, R.B.; Langdon, T.G. Orientation imaging microscopy and microhardness in a ZK60 magnesium alloy processed by high-pressure torsion. J. Alloys Compd. 2017, 712, 185-193. [CrossRef]

38. Korneva, A.; Straumal, B.; Kilmametov, A.; Cios, G.; Bała, P.; Zięba, P. Effect of high pressure torsion on microstructure of Cu-Sn alloys with different content of Hume Rothery phase. Mater. Charact. 2016, 118, 411-416. [CrossRef]

39. Straumal, B.B.; Pontikis, V.; Kilmametov, A.R.; Mazilkin, A.A.; Dobatkin, S.V.; Baretzky, B. Competition between precipitation and dissolution in $\mathrm{Cu}-\mathrm{Ag}$ alloys under high pressure torsion. Acta Mater. 2017, 122, 60-71. [CrossRef]

40. Straumal, B.B.; Kilmametov, A.R.; Kogtenkova, O.A.; Mazilkin, A.A.; Baretzky, B.; Korneva, A.; Zięba, P. Phase transitions in copper-silver alloys under high pressure torsion. Int. J. Mater. Res. 2019, 110, 608-613. [CrossRef]

41. Straumal, B.B.; Kilmametov, A.R.; Baretzky, B.; Kogtenkova, O.A.; Straumal, P.B.; Lityńska-Dobrzyńska, L.; Chulist, R.; Korneva, A.; Zięba, P. High pressure torsion of $\mathrm{Cu}-\mathrm{Ag}$ and $\mathrm{Cu}-\mathrm{Sn}$ alloys: Limits for solubility and dissolution. Acta Mater. 2020, 195, 184-198. [CrossRef]

42. Straumal, B.B.; Kilmametov, A.R.; Ivanisenko, Y.; Mazilkin, A.A.; Kogtenkova, O.A.; Kurmanaeva, L.; Korneva, A.; Zięba, P.; Baretzky, B. Phase transitions induced by severe plastic deformation: Steady-state and equifinality. Int. J. Mater. Res. 2015, 106, 657-664. [CrossRef]

43. Edalati, K.; Horita, Z. High-pressure torsion of pure metals: Influence of atomic bond parameters and stacking fault energy on grain size and correlation with hardness. Acta Mater. 2011, 59, 6831-6836. [CrossRef]

44. Edalati, K.; Lee, D.J.; Nagaoka, T.; Arita, M.; Kim, H.S.; Horita, Z.; Pippan, R. Real hydrostatic pressure in high-pressure torsion measured by bismuth phase transformations and FEM simulations. Mater. Trans. 2016, 57, 533-538. [CrossRef]

45. Edalati, K.; Horita, Z.; Furuta, T.; Kuramoto, S. Dynamic recrystallization and recovery during high-pressure torsion: Experimental evidence by torque measurement using ring specimens. Mater. Sci. Eng. A 2013, 559, 506-509. [CrossRef]

46. Beygelzimer, Y.; Kulagin, R.; Toth, L.S.; Ivanisenko, Y. The self-similarity theory of high pressure torsion. Beilstein J. Nanotechnol. 2016, 7, 1267-1277. [CrossRef] [PubMed]

47. Otto, F.; Dlouhý, A.; Pradeep, K.G.; Kubénová, M.; Raabe, D.; Eggeler, G.; George, E.P. Decomposition of the single-phase high-entropy alloy CrMnFeCoNi after prolonged anneals at intermediate temperatures. Acta Mater. 2016, 112, 40-52. [CrossRef]

48. Mazilkin, A.A.; Straumal, B.B.; Rabkin, E.; Baretzky, B.; Enders, S.; Protasova, S.G.; Kogtenkova, O.A.; Valiev, R.Z. Softening of nanostructured Al-Zn and Al-Mg alloys after severe plastic deformation. Acta Mater. 2006, 54, 3933-3939. [CrossRef]

49. Shahmir, H.; Nili-Ahmadabadi, M.; Shafiee, A.; Langdon, T.G. Effect of a minor titanium addition on the superplastic properties of a CoCrFeNiMn high-entropy alloy processed by high-pressure torsion. Mater. Sci. Eng. A 2018, 718, 468-476. [CrossRef]

50. Shahmir, H.; Nili-Ahmadabadi, M.; Shafiee, A.; Andrzejczuk, M.; Lewandowska, M.; Langdon, T.G. Effect of Ti on phase stability and strengthening mechanisms of a nanocrystalline CoCrFeMnNi high-entropy alloy. Mater. Sci. Eng. A 2018, 725, 196-206. [CrossRef]

51. Shahmir, H.; He, J.; Lu, Z.; Kawasaki, M.; Langdon, T.G. Effect of annealing on mechanical properties of a nanocrystalline CoCrFeNiMn high-entropy alloy processed by high-pressure torsion. Mater. Sci. Eng. A 2016, 676, 294-303. [CrossRef]

52. Shahmir, H.; Mousavi, T.; He, J.; Lu, Z.; Kawasaki, M.; Langdon, T.G. Microstructure and properties of a CoCrFeNiMn highentropy alloy processed by equal-channel angular pressing. Mater. Sci. Eng. A 2017, 705, 411-419. [CrossRef]

53. Reddy, T.S.; Wani, I.S.; Bhattacharjee, T.; Reddy, S.R.; Saha, R.; Bhattacharjee, P.P. Severe plastic deformation driven nanostructure and phase evolution in a $\mathrm{Al}_{0.5} \mathrm{CoCrFeMnNi}$ dual phase high entropy alloy. Intermetallics 2017, 91, 150-157. [CrossRef]

54. Schuh, B.; Mendez-Martin, F.; Völker, B.; George, E.P.; Clemens, H.; Pippan, R.; Hohenwarter, A. Mechanical properties, microstructure and thermal stability of a nanocrystalline CoCrFeMnNi high-entropy alloy after severe plastic deformation. Acta Mater. 2015, 96, 258-268. [CrossRef]

55. Moon, J.; Qi, Y.; Tabachnikova, E.; Estrin, Y.; Choi, W.-M.; Joo, S.-H.; Lee, B.-J.; Podolskiy, A.; Tikhonovsky, M.; Kim, H.S Microstructure and mechanical properties of high-entropy alloy $\mathrm{Co}_{20} \mathrm{Cr}_{26} \mathrm{Fe}_{20} \mathrm{Mn}_{20} \mathrm{Ni}_{14}$ processed by high-pressure torsion at 77 K and 300 K. Sci. Rep. 2018, 8, 11074. [CrossRef]

56. Moon, J.; Qi, Y.; Tabachnikova, E.; Estrin, Y.; Choi, W.-M.; Joo, S.-H.; Lee, B.-J.; Podolskiy, A.; Tikhonovsky, M.; Kim, H.S. Deformation-induced phase transformation of $\mathrm{Co}_{20} \mathrm{Cr}_{26} \mathrm{Fe}_{20} \mathrm{Mn}_{20} \mathrm{Ni}_{14}$ high-entropy alloy during high-pressure torsion at $77 \mathrm{~K}$. Mater. Lett. 2017, 202, 86-88. [CrossRef]

57. Xu, C.; Horita, Z.; Langdon, T.G. Microstructural evolution in an aluminum solid solution alloy processed by ECAP. Mater. Sci. Eng. A 2011, 528, 6059-6065. [CrossRef] 
58. Edalati, K.; Horita, Z. Significance of homologous temperature in softening behavior and grain size of pure metals processed by high-pressure torsion. Mater. Sci. Eng. A 2011, 528, 7514-7523. [CrossRef]

59. Korznikov, A.V.; Ivanisenko, Y.V.; Laptionok, D.V.; Safarov, I.M.; Pilyugin, V.P.; Valiev, R.Z. Influence of severe plastic deformation on structure and phase composition of carbon steel. Nanostruct. Mater. 1994, 4, 159-167. [CrossRef]

60. Ivanisenko, Y.; Lojkowski, W.; Valiev, R.Z.; Fecht, H.-J. Formation of nanostructure and dissolution of cementite in a pearlitic steel during high pressure torsion. Acta Mater. 2003, 51, 5555-5570. [CrossRef]

61. Ivanisenko, Y.; Wunderlich, R.K.; Valiev, R.Z.; Fecht, H.-J. Annealing behaviour of nanostructured carbon steel produced by severe plastic deformation. Scr. Mater. 2003, 49, 947-952. [CrossRef]

62. Zrnik, J.; Pippan, R.; Scheriau, S.; Kraus, L.; Fujda, M. Microstructure and mechanical properties of UFG medium carbon steel processed by HPT at increased temperature. J. Mater. Sci. 2010, 45, 4822-4826. [CrossRef]

63. Bayramoglu, S.; Gür, C.H.; Alexandrov, I.V.; Abramova, M.M. Characterization of ultra-fine grained steel samples produced by high pressure torsion via magnetic Barkhausen noise analysis. Mater. Sci. Eng. A 2010, 527, 927-933. [CrossRef]

64. Ning, J.; Courtois-Manara, E.; Kurmanaeva, L.; Ganeev, A.V.; Valiev, R.Z.; Kübel, C.; Ivanisenko, Y. Tensile properties and work hardening behaviors of ultrafine grained carbon steel and pure iron processed by warm high pressure torsion. Mater. Sci. Eng. A 2013, 581, 8-15. [CrossRef]

65. Todaka, Y.; Miki, Y.; Umemoto, M.; Wang, C.; Tsuchiya, K. Tensile property of submicrocrystalline pure Fe produced by HPT-straining. Mater. Sci. Forum 2008, 584-586, 597-604. [CrossRef]

66. Borchers, C.; Garve, C.; Tiegel, M.; Deutges, M.; Herz, A.; Edalati, K.; Pippan, R.; Horita, Z.; Kirchheim, R. Nanocrystalline steel obtained by mechanical alloying of iron and graphite subsequently compacted by high-pressure torsion. Acta Mater. 2015, 97, 207-215. [CrossRef]

67. Liao, X.Z.; Kilmametov, A.R.; Valiev, R.Z.; Gao, H.; Li, X.; Mukherjee, A.K.; Bingert, J.F.; Zhu, Y.T. High-pressure torsion-induced grain growth in electrodeposited nanocrystalline Ni. Appl. Phys. Lett. 2006, 88, 021909. [CrossRef]

68. Pippan, R.; Scheriau, S.; Taylor, A.; Hafok, M.; Hohenwarter, A.; Bachmaier, A. Saturation of fragmentation during severe plastic deformation. Annu. Rev. Mater. Res. 2010, 40, 319-343. [CrossRef]

69. Wen, H.; Islamgaliev, R.K.; Nesterov, K.M.; Valiev, R.Z.; Lavernia, E.J. Dynamic balance between grain refinement and grain growth during high-pressure torsion of Cu powders. Phil. Mag. Lett. 2013, 93, 481-489. [CrossRef]

70. Diez, M.; Kim, H.-E.; Serebryany, V.; Dobatkin, S.; Estrin, Y. Improving the mechanical properties of pure magnesium by three-roll planetary milling. Mater. Sci. Eng. A 2014, 612, 287-292. [CrossRef]

71. Lukyanova, E.A.; Martynenko, N.S.; Shakhova, I.; Belyakov, A.N.; Rokhlin, L.L.; Dobatkin, S.V.; Estrin, Y.Z. Strengthening of age-hardenable WE43 magnesium alloy processed by high pressure torsion. Mater. Lett. 2016, 170, 5-9. [CrossRef]

72. Martynenko, N.S.; Luk'yanova, E.A.; Morozov, M.M.; Yusupov, V.S.; Dobatkin, S.V.; Estrin, Y.Z. A study of the structure, mechanical properties and corrosion resistance of magnesium alloy WE43 after rotary swaging. Metal Sci. Heat Treat. 2018, 60, 253-258. [CrossRef]

73. Koch, C.C.; Langdon, T.G.; Lavernia, E.J. Bulk nanostructured materials. Metal. Mater. Trans. A 2017, 48, 5182-5199. [CrossRef]

74. Kulagin, R.; Zhao, Y.; Beygelzimer, Y.; Toth, L.S.; Shtern, M. Modeling strain and density distributions during high-pressure torsion of pre-compacted powder materials. Mater. Res. Lett. 2017, 5, 179-186. [CrossRef]

75. Kormout, K.S.; Pippan, R.; Bachmaier, A. Deformation-induced supersaturation in immiscible material systems during highpressure torsion. Adv. Eng. Mater. 2017, 19, 1600675. [CrossRef]

76. Straumal, B.B.; Kilmametov, A.R.; Korneva, A.; Mazilkin, A.A.; Straumal, P.B.; Zięba, P.; Baretzky, B. Phase transitions in Cu-based alloys under high pressure torsion. J. Alloys Comp. 2017, 707, 20-26. [CrossRef]

77. Straumal, B.B.; Protasova, S.G.; Mazilkin, A.A.; Rabkin, E.; Goll, D.; Schütz, G.; Baretzky, B.; Valiev, R. Deformation-driven formation of equilibrium phases in the Cu-Ni alloys. J. Mater. Sci. 2012, 47, 360-367. [CrossRef]

78. Pant, N.; Verma, N.; Ashkenazy, Y.; Bellon, P.; Averback, R.S. Phase evolution in two-phase alloys during severe plastic deformation. Acta Mater. 2021, 210, 116826. [CrossRef]

79. Sabirov, I.; Pippan, R. Formation of a W-25\%Cu nanocomposite during high pressure torsion. Scr. Mater. 2005, 52, 1293-1298. [CrossRef]

80. Edwards, D.; Sabirov, I.; Sigle, W.; Pippan, R. Microstructure and thermostability of a W-Cu nanocomposite produced via high-pressure torsion. Phil. Mag. 2012, 92, 4151-4166. [CrossRef]

81. Sabirov, I.; Pippan, R. Characterization of tungsten fragmentation in a W-25\%Cu composite after high-pressure torsion. Mater. Charact. 2007, 58, 848-853. [CrossRef]

82. Bachmaier, A.; Schmauch, J.; Aboulfadl, H.; Verch, A.; Motz, C. On the process of co-deformation and phase dissolution in a hard-soft immiscible CueCo alloy system during high-pressure torsion deformation. Acta Mater. 2016, 115, 333-346. [CrossRef]

83. Bachmaier, A.; Aboulfadl, H.; Pfaff, M.; Mücklich, F.; Motz, C. Structural evolution and strain induced mixing in Cu-Co composites studied by transmission electron microscopy and atom probe tomography. Mater. Charact. 2015, 100, 178-191. [CrossRef] [PubMed]

84. Bachmaier, A.; Rathmayr, G.B.; Bartosik, M.; Apel, D.; Zhang, Z.; Pippan, R. New insights on the formation of supersaturated solid solutions in the $\mathrm{Cu}-\mathrm{Cr}$ system deformed by high-pressure torsion. Acta Mater. 2014, 69, 301-313. [CrossRef]

85. Korneva, A.; Straumal, B.; Kilmametov, A.; Chulist, R.; Cios, G.; Baretzky, B.; Zięba, P. Dissolution of Ag precipitates in the $\mathrm{Cu}-8 \mathrm{wt} . \% \mathrm{Ag}$ alloy deformed by high pressure torsion. Materials 2019, 12, 447. [CrossRef] 
86. Hosseini, M.; Pardis, N.; Manesh, H.D.; Abbasi, M.; Kimb, D.-I. Structural characteristics of Cu/Ti bimetal composite produced by accumulative roll-bonding (ARB). Mater. Design 2017, 113, 128-136. [CrossRef]

87. Shin, D.H.; Park, K.-T.; Kim, Y.-S. Formation of fine cementite precipitates in an ultra-fine grained low carbon steel. Scr. Mater. 2003, 48, 469-473. [CrossRef]

88. Wetscher, F.; Vorhauer, A.; Stock, R.; Pippan, R. Structural refinement of low alloyed steels during severe plastic deformation. Mater. Sci. Eng. A 2004, 387-389, 809-816. [CrossRef]

89. Ivanisenko, Y.; Sauvage, X.; Mazilkin, A.; Kilmametov, A.; Beach, J.A.; Straumal, B.B. Bulk nanocrystalline ferrite stabilized through grain boundary carbon segregation. Adv. Eng. Mater. 2018, 20, 1800443. [CrossRef]

90. Cubero-Sesin, J.M.; Horita, Z. Strengthening via microstructure refinement in bulk Al—4 mass.\% Fe alloy using high-pressure torsion. Mater. Trans. 2012, 53, 46-55. [CrossRef]

91. Boucharat, N.; Hebert, R.; Rösner, H.; Valiev, R.; Wilde, G. Nanocrystallization of amorphous $\mathrm{Al}_{88} \mathrm{Y}_{7} \mathrm{Fe}_{5}$ alloy induced by plastic deformation. Scr. Mater. 2005, 53, 823-828. [CrossRef]

92. Henits, P.; Révész, Á.; Zhilyaev, A.P.; Kovács, Z.S. Severe plastic deformation induced nanocrystallization of melt-spun $\mathrm{Al}_{85} \mathrm{Y}_{8} \mathrm{Ni}_{5} \mathrm{Co}_{2}$ amorphous alloy. J. Alloys Compd. 2008, 461, 195-199. [CrossRef]

93. Pershina, E.; Abrosimova, G.; Aronin, A.; Matveev, D.; Tkatch, V. Crystallization features in $\mathrm{Al}_{90} \mathrm{Y}_{10}$ amorphous alloy under a various external influence. Mater. Lett. 2014, 134, 60-63. [CrossRef]

94. Pershina, E.; Matveev, D.; Abrosimova, G.; Aronin, A. Formation of nanocrystals in an amorphous $\mathrm{Al}_{90} \mathrm{Y}_{10}$ alloy. Mater. Charact. 2017, 133, 87-93. [CrossRef]

95. Kovács, Z.; Henits, P.; Zhilyaev, A.P.; Révész, Á. Deformation induced primary crystallization in a thermally non-primary crystallizing amorphous $\mathrm{Al}_{85} \mathrm{Ce}_{8} \mathrm{Ni}_{5} \mathrm{Co}_{2}$ alloy. Scr. Mater. 2006, 54, 1733-1737. [CrossRef]

96. Henits, P.; Révész, Á.; Varga, L.K.; Kovács, Z.S. The evolution of the microstructure in amorphous $\mathrm{Al}_{85} \mathrm{Ce}_{8} \mathrm{Ni}_{5} \mathrm{Co}_{2}$ alloy during heat treatment and severe plastic deformation: A comparative study. Intermetallics 2011, 19, 267-275. [CrossRef]

97. Abrosimova, G.; Aronin, A.; Matveev, D.; Pershina, E. Nanocrystal formation, structure and magnetic properties of Fe-Si-B amorphous alloy after deformation. Mater. Lett. 2013, 97, 15-17. [CrossRef]

98. Li, W.; Li, L.; Nan, Y.; Xu, Z.; Zhang, X.; Popov, A.G.; Gunderov, D.V.; Stolyarov, V.V. Nanocrystallization and magnetic properties of amorphous $\mathrm{Nd}_{9} \mathrm{Fe}_{85} \mathrm{~B}_{6}$ subjected to high-pressure torsion deformation upon annealing. J. Appl. Phys. 2008, 104, 023912. [CrossRef]

99. Li, W.; Li, X.; Guo, D.; Sato, K.; Gunderov, D.V.; Stolyarov, V.V.; Zhang, X. Atomic-scale structural evolution in amorphous $\mathrm{Nd}_{9} \mathrm{Fe}_{85} \mathrm{~B}_{6}$ subjected to severe plastic deformation at room temperature. Appl. Phys. Lett. 2009, 94, 231904. [CrossRef]

100. Hóbor, P.; Révész, Á.; Zhilyaev, A.P.; Kovács, Z.S. Different nanocrystallization sequence during high pressure torsion and thermal treatments of amorphous $\mathrm{Cu}_{60} \mathrm{Zr}_{20} \mathrm{Ti}_{20}$ alloy. Rev. Adv. Mater. Sci. 2008, 18, 590-592.

101. Ubyivovk, E.V.; Boltynjuk, E.V.; Gunderov, D.V.; Churakova, A.A.; Kilmametov, A.R.; Valiev, R.Z. HPT-induced shear banding and nanoclustering in a TiNiCu amorphous alloy. Mater. Lett. 2017, 209, 327-329. [CrossRef]

102. Gunderov, D.V.; Boltynjuk, E.V.; Ubyivovk, E.V.; Lukyanov, A.V.; Churakova, A.A.; Kilmametov, A.R.; Zamula, Y.S.; Valiev, R.Z. Cluster structure in amorphous Ti-Ni-Cu alloys subjected to highpressure torsion deformation. J. Alloys Compd. 2018, 749, 612-619. [CrossRef]

103. Kovács, Zs.; Schafler, E.; Kovács Kisc, V.; Szommer, P.J.; Révész, Á. High pressure torsion of a Vitreloy bulk metallic glass near the glass transition temperature. J. Non-Cryst. Solids 2018, 498, 25-31. [CrossRef]

104. Yamada, M.; Kamisato, R.; Yamasaki, T.; Adachi, H.; Tsuchiya, K.; Yokoyama, Y. Nanocrystallization of Zr-Cu-Ni-Al-Au glassy alloys during severe plastic deformation. IOP Conf. Ser. Mater. Sci. Eng. 2014, 63, 012167. [CrossRef]

105. Vierke, J.; Schumacher, G.; Pilyugin, V.P.; Denks, I.A.; Zizak, I.; Wolf, C.; Wanderka, N.; Wollgarten, M.; Banhart, J. Deformationinduced crystallization in amorphous $\mathrm{Al}_{85} \mathrm{Ni}_{10} \mathrm{La}_{5}$ alloy. J. Alloys Compd. 2010, 493, 683-691. [CrossRef]

106. Permyakova, I.; Glezer, A. Amorphous-nanocrystalline composites prepared by high-pressure torsion. Metals 2020, 10, 511. [CrossRef]

107. Pushin, V.G.; Kuranova, N.N.; Pushin, A.V.; Valiev, R.Z.; Kourov, N.I.; Teplykh, A.E.; Uksusnikov, A.N. Formation of nanocrystalline structure in the amorphous $\mathrm{Ti}_{50} \mathrm{Ni}_{25} \mathrm{Cu}_{25}$ alloy upon severe thermomechanical treatment and the size effect of the thermoelastic martensitic B2 $\leftrightarrow$ B19 transformation. Phys. Met. Metallogr. 2012, 113, 271-282. [CrossRef]

108. Pushin, V.G.; Kuranova, N.N.; Pushin, A.V.; Kourov, N.I.; Pilyugin, V.P. Formation of the nanocrystalline structure in the $\mathrm{Ti}_{50} \mathrm{Ni}_{25} \mathrm{Cu}_{25}$ shape memory alloy under severe thermomechanical treatment. Phys. Met. Metallogr. 2011, 112, 603-612. [CrossRef]

109. Henits, P.; Kovács, Z.S.; Schafler, E.; Varga, L.K.; Lábár, J.L.; Révész, Á. Nanocrystallization in $\mathrm{Al}_{85} \mathrm{Ce}_{8} \mathrm{Ni}_{5} \mathrm{Co}_{2}$ amorphous alloy obtained by different strain rate during high pressure torsion. J. Alloys Compd. 2010, 504S, S91-S94. [CrossRef]

110. Henits, P.; Kovács, Zs.; Varga, L.K.; Révész, Á. Nanocrystallization in $\mathrm{Al}_{85} \mathrm{Ce}_{8} \mathrm{Ni}_{5} \mathrm{Co}_{2}$ amorphous alloy induced by heat treatment and severe plastic deformation. J. Phys. Conf. Ser. 2009, 144, 012095. [CrossRef] 